
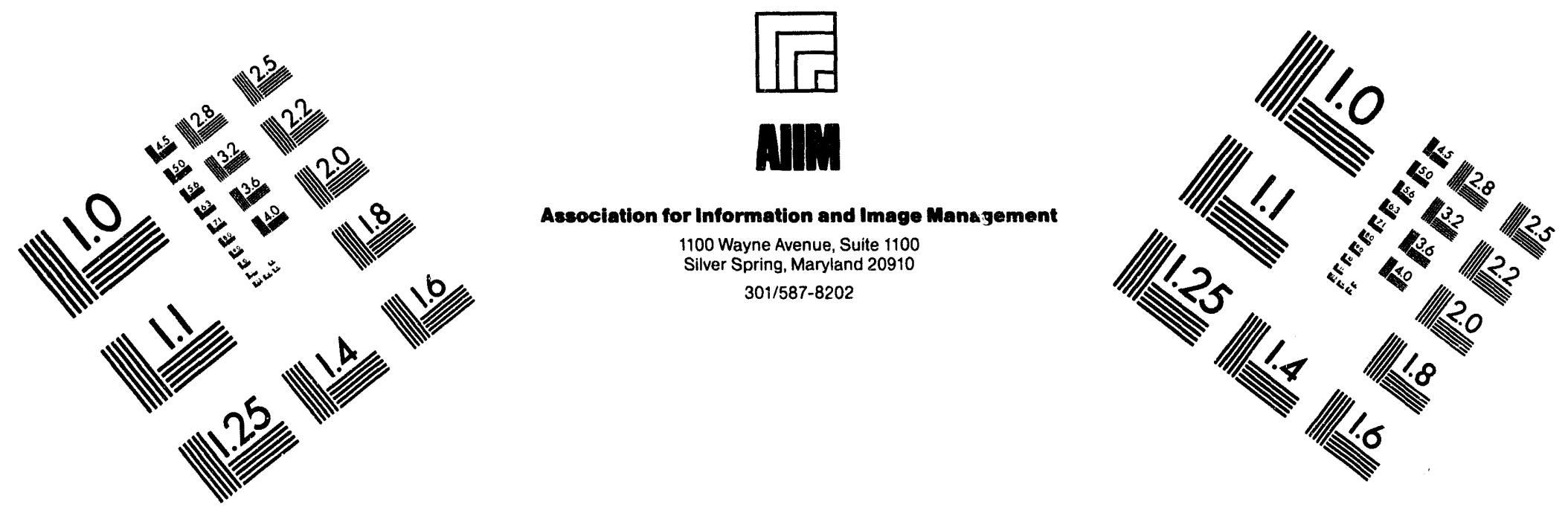

Centimeter

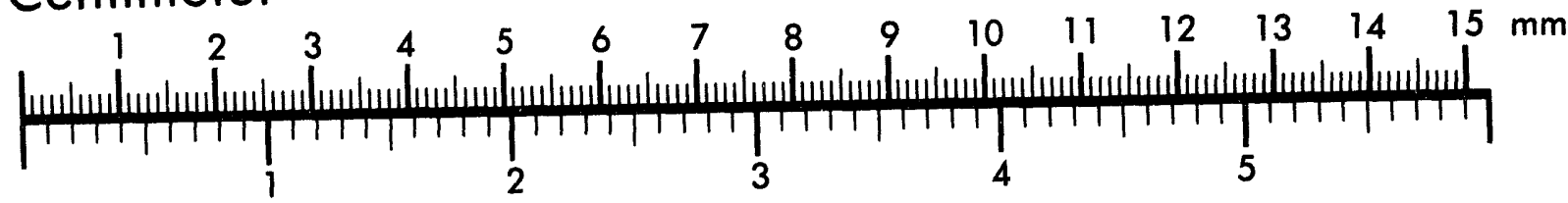

Inches
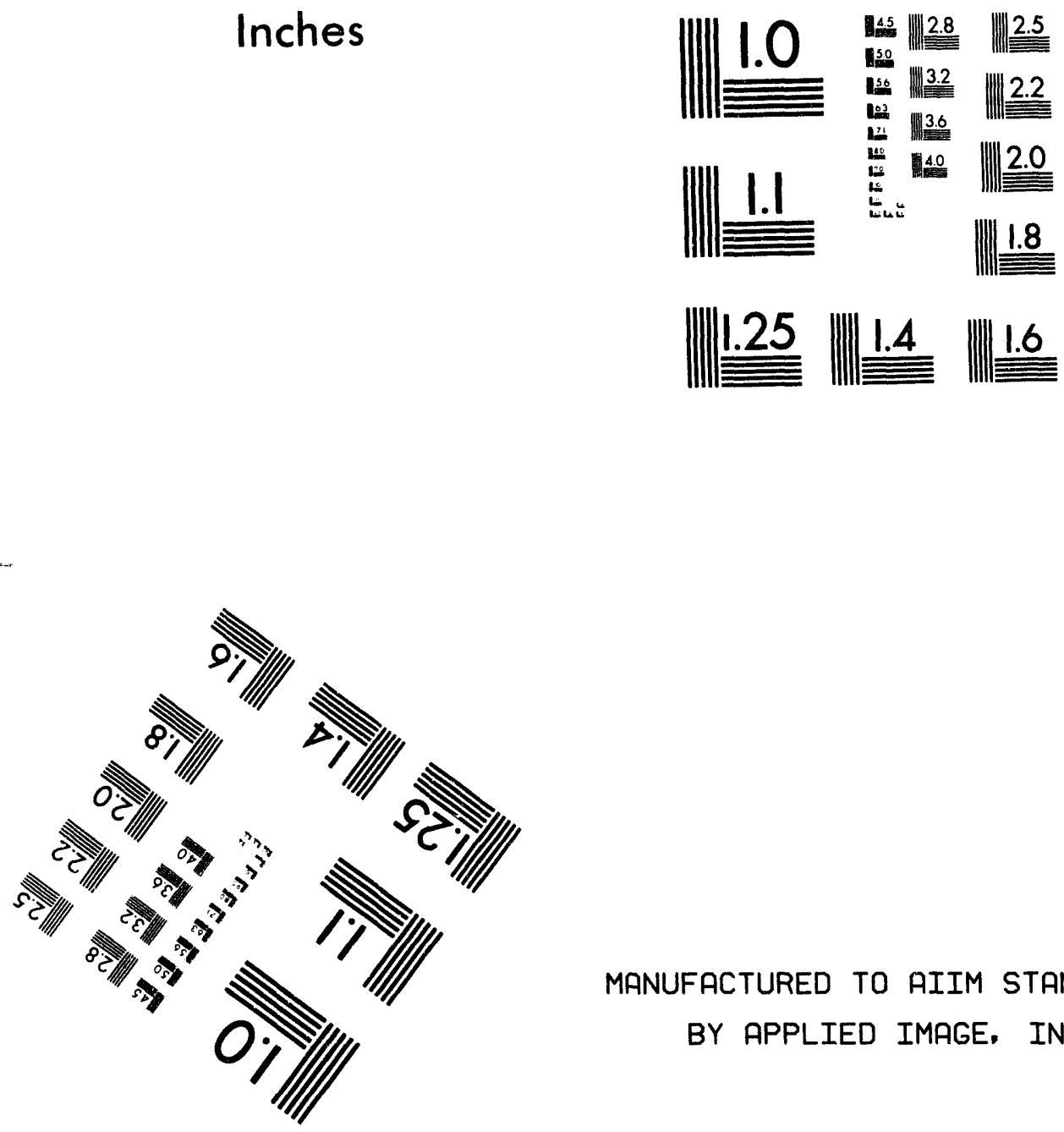

MANUFACTURED TO AIIM STANDARDS

BY APPLIED IMAGE, INC.

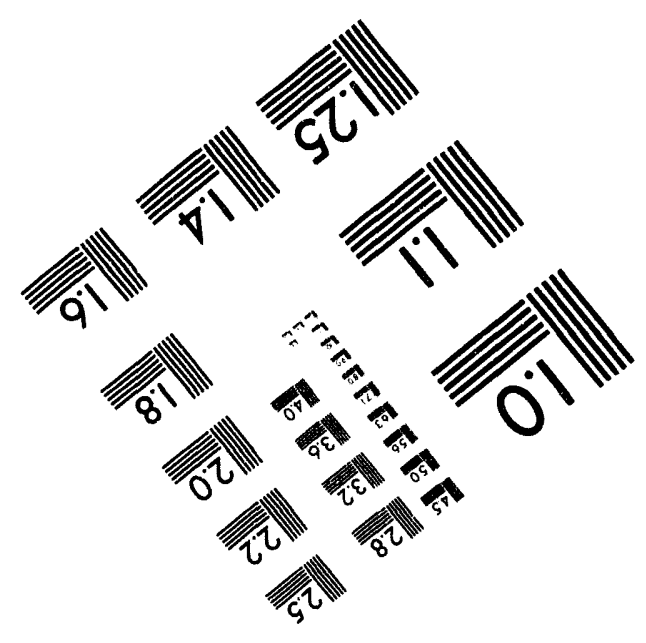



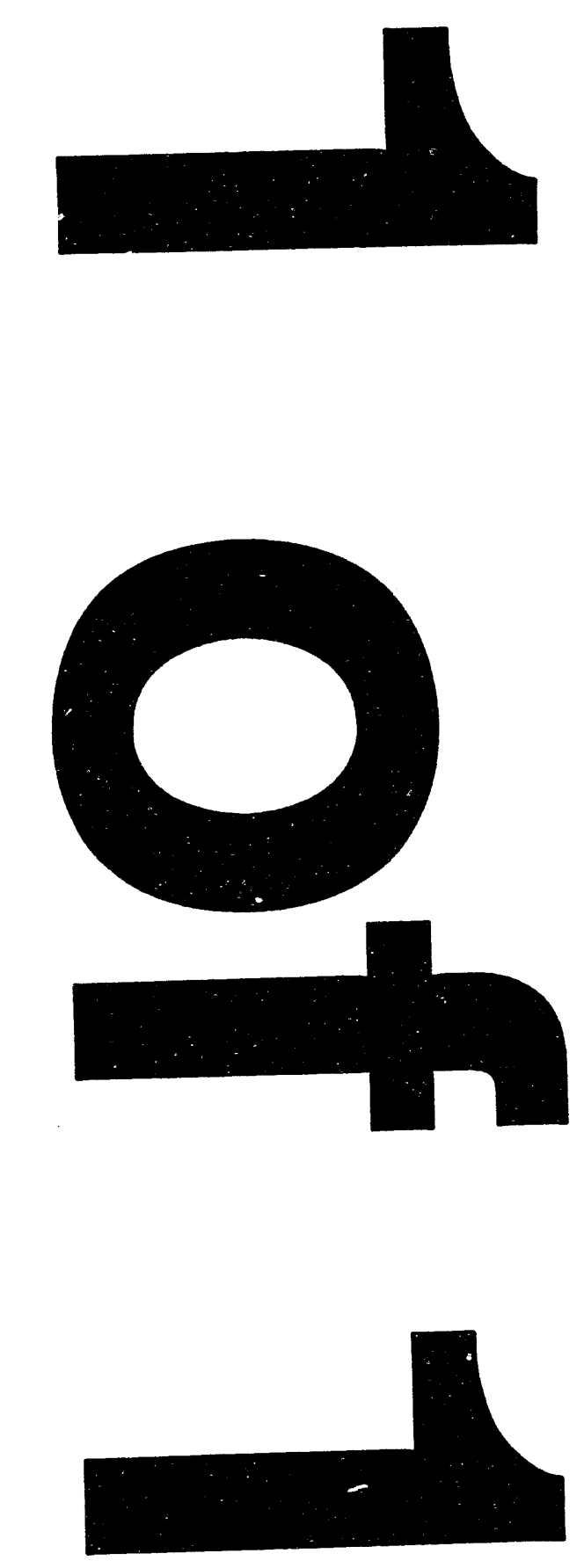


\title{
Progress Report on Terrestrial Model Development (TERRA and HABITAT): Research in Support of the CERES Earth System Modeling Project
}

\author{
J.R. Kercher ${ }^{1}$, J.Q. Chambers ${ }^{2,4}$ M.C. Axelrod ${ }^{3}$, J.S. Amthor ${ }^{1}$ \\ ${ }^{1}$ Health and Ecological Assessment Division, L-256, \\ 2Global Climate Research Division, ${ }^{3}$ Engineering Research Division \\ Lawrence Livermore National Laboratory, University of California, \\ Livermore, CA 94550 \\ and ${ }^{4}$ Department of Biological Sciences \\ University of California, Santa Barbara, CA 95616
}




\section{Introduction and Scope of Work}

Although there is only a developing understanding of the many processes affecting and coupling the atmosphere, oceans, and land systems of the Earth, we are embarked on an effort to construct a prototype model (CERES) of the full Earth System. As part of this effort, we have proposed to EPA to construct an Earth System Framework for the CERES model that supports flexible, modular development, coupling, and replacement of Earth System submodel components. Additionally for this project, we have been undertaken the intensive study of processes internal to the Terrestrial Ecosystem component of the Earth System and intensive development of the corresponding Terrestrial System models. We are motivated by the desire to start exploration of the many coupling processes and to improve understanding of their importance and the degree to which our ability to represent each must be improved. As a step toward the long-term objective set by the U.S. Global Change Research Program of developing a predictive understanding of the Earth system for use in evaluating the effects of changing greenhouse gas and aerosol concentrations, w $e$ are now constructing a framework model that includes the UCLA atmospheric general circulation model AGCM (Arakawa and Lamb 1977), the ocean general circulation model of the Geophysical Fluid Dynamics Laboratory (Manabe et al. 1991), the LLNL atmospheric chemistry model GRANTOUR(Walton et al. 1988, Penner et al. 1991), the land surface model Biosphere-Atmosphere Transfer Scheme (BATS) (Dickinson et al. 1986), and models of the terrestrial ecosystem that we are constructing and are described in this report.

The atmosphere is strongly influenced by the boundary conditions at the Earth's surface. The boundary conditions are, in turn, determined by the state of the ecosystems on the land portion of the globe. The interactions between the atmospheric state (weather and climate) and land ecosystems work in both directions. The atmospheric state influences the distribution and growth of vegetation on the land surface and the state of vegetation influences the climate. Secondly, the biological influences on the cycling of carbon, nitrogen, etc. on the land surface affect atmospheric concentrations of carbon dioxide, nitrogen oxides, etc. Likewise, the concentrations of these compounds in the atmosphere affect their deposition and biological uptake. Thus, to simulate the dynamics of the greenhouse gases and climate change, the model must include the biology occurring at the Earth's surface.

Areas of Study. The terrestrial ecosystem subproject has two specific areas of study. The first area is the terrestrial contribution to biogeochemical cycling within the Earth System. Our objectives within this first area are: (1) to develop a globally distributed model of terrestrial ecosystem productivity and elemental cycling (TERRA) using a grid structure similar to that of a general circulation model (GCM); (2) to link this model to the CERES submodels of atmospheric chemistry and ocean biogeochemistry; and (3) to use this coupled system to explore the dynamics of global biogeochemical cycles and greenhouse gas concentrations. The second area of study is the interactions of climate and land ecosystems. Our objectives within this second area are: (1) to develop models of vegetation response to climate (HABITAT); (2) to couple the CERES atmospheric, land surface, and HABITAT submodels together as a fully interacting combination; and (3) to study the dynamics of climate change and vegetation response.

\section{Progress Prior to October 1992}

While the EPA project began in FY93, work on terrestrial model development began in FY92 under the auspices of the Earth System Modeling Director's Initiative funded from the internal Laboratory Directed Research program. In FY92, we developed the local ecosystem productivity and biogeochemical cycling model from which the global model is constructed. The local ecosystem model is a generic productivity-and-cycling 
model that calculates water fluxes of evaporation, transpiration, and runoff; carbon fluxes of gross primary productivity, litterfall, and respiration; and nitrogen fluxes of vegetation uptake, litterfall, mineralization, and system loss. The state variables are soil water content, carbon in live vegetation, carbon in soil, nitrogen in live vegetation, organic nitrogen in soil and litter, and available inorganic nitrogen aggregating nitrites, nitrates, and ammonia. The water balance model is based on the DAYTRANS model of Running (1984) and the cycling model is based on TEM of Raich et al (1991).

Description of TERRA. We have constructed the grid-cell model for the 17 vegetation types. The five ordinary, coupled, nonlinear differential equations for the five carbon and nitrogen state variables are based on TEM (Raich et al. 1991) with their structure given by

$$
\begin{aligned}
& \frac{d y_{1}}{d t}=C_{\max }\left(1-r_{8 f}\right) f_{1}\left(P A R, C_{a}, T, y_{6}, A E ;\left\{p_{i}\right\}\right)-K_{r}\left(1-r_{8 f}\right) y_{1} f_{2}\left(T ;\left\{p_{i}\right\}\right)-K_{\text {fall }} y_{1} \\
& \frac{d y_{2}}{d t}=K_{\text {fall }} y_{1}-K_{d} y_{2} f_{3}\left(T, S M ;\left\{p_{i}\right\}\right) \\
& \frac{d y_{3}}{d t}=N_{\max } y_{5} f_{4}\left(y_{5}, T, y_{6} ;\left\{p_{i}\right\}\right)-L_{N C} K_{\text {fall }} y_{3} f_{5}(\{p\}) \\
& \frac{d y_{4}}{d t}=L_{N C} K_{\text {fall }} y_{3} f_{5}\left(\left\{p_{i}\right\}\right)-\left[N_{u p} y_{5} f_{6}\left(y_{5}, y_{2}, T, S M ;\left\{p_{i}\right\}\right)+K_{d} y_{4} f_{3}\left(T, S M ;\left\{p_{i}\right\}\right)\right] \\
& \frac{d y_{5}}{d t}=N_{\text {input }}+\left[N_{u p} y_{5} f_{6}\left(y_{5}, y_{2}, T, S M ;\left\{p_{i}\right\}\right)+K_{d} y_{4} f_{3}\left(T, S M ;\left\{p_{i}\right\}\right)\right] \\
& -N_{\max } y_{5} f_{4}\left(y_{5}, T, y_{6} ;\left\{p_{i}\right\}\right)-N_{\text {Loss }} y_{5}
\end{aligned}
$$

where $y_{1}$ is the carbon content of vegetation $\left(\mathrm{g} \mathrm{C} \mathrm{m}^{-2}\right), y_{2}$ is the carbon content of the soil $\left(\mathrm{g} \mathrm{C} \mathrm{m}^{-2}\right), y_{3}$ is the content of nitrogen in vegetation $\left(\mathrm{g} \mathrm{N} \mathrm{m}^{-2}\right), y_{4}$ is the organic $\mathrm{N}$ in soil and detritus $\left(\mathrm{g} \mathrm{N} \mathrm{m}^{-2}\right)$, and $y_{5}$ is the inorganic or available content of nitrogen in soil $(\mathrm{g} \mathrm{N}$ $\left.\mathrm{m}^{-2}\right)$. The unit of time $(t)$ is years. $P A R$ is the photosynthetically active radiation $\left(\mathrm{W} \mathrm{m}^{-2}\right)$, $C_{a}$ is the concentration of $\mathrm{CO}_{2}$ in the atmosphere $\left(\mu \mathrm{l}^{-1}\right), T$ is the air temperature $(\operatorname{deg} \mathrm{C})$, $A E$ is the actual evapotranspiration $(\mathrm{m}),\left\{p_{i}\right\}$ is the set of model parameters, $S M$ is the soil water content (percent of saturation), and $y_{6}$ is a unitless state variable governing allocation where carbon assimilation is maximized when $y_{6}$ equals 1 and nitrogen uptake is maximized when $y_{6}$ equals 0 . Details of the individual terms and the functions $f_{1}$ through $f_{6}$ in these equations are given in Raich et al. (1991). In eq. 1 , the term containing $C_{\text {max }}$ is gross primary productivity (GPP) less a portion of growth respiration $\left(R_{g}\right)$; the term with $K_{r}$ is plant maintenance respiration $\left(R_{m}\right)$ less the remaining growth respiration; and the term with $K_{\text {fall }}$ is litterfall $\left(L_{c}\right)$. In eq. 2 , the term containing $K_{d}$ is soil respiration $\left(R_{h}\right)$. In eq. 3 , the term with $N_{\max }$ is plant uptake of nitrogen; the $L_{N C}$ term is the nitrogen loss from plant due to litterfall. In eq. 4 , the $N_{u p}$ term is nitrogen immobilization by bacteria, and the $K_{d}$ term is the rate of nitrogen release by decomposition and mineralization. In eq. 5 , the $N_{\text {input }}$ term is the input of nitrogen from outside the grid cell (dryfall, wetfall, and fixation); the $N_{\text {LOSS }}$ term is the loss of nitrogen from the system (nitrogen loss due to nitrogen content of leachate and runoff and nitrification to gaseous compounds). 
The parameters that are fixed by calibration are $C_{\max }$, the maximum gross fixation of carbon (maximum efficiency of light harvesting $\times$ maximum rate of carbon uptake by Calvin cycle $\times$ maximum rate of transfer of carbon into leaf $\times$ maximum leaf area index) $(g$ $\left.\mathrm{m}^{-2} \mathrm{yr}^{-1}\right) ; K_{r}$, specific respiration rate of vegetation extrapolated to $0^{\circ} \mathrm{C}$ ( $\mathrm{g} \mathrm{C}$ respired $\mathrm{g}^{-1} \mathrm{C}$ standing crop $\left.\mathrm{yr}^{-1}\right) ; K_{\text {fall }}$, specific litterfall rate $\left(\mathrm{g} \mathrm{C}\right.$ litter $\mathrm{g}^{-1} \mathrm{C}$ standing crop vegetation yr $\left.{ }^{1}\right) ; K_{d}$, specific soil respiration rate ( $\mathrm{g} \mathrm{C}$ soil respiration $\mathrm{g}^{-1} \mathrm{C}$ soil carbon $\mathrm{yr}^{-1}$ ); $N_{\max }$, maximum rate of $\mathrm{N}$ uptake by vegetation in $\mathrm{g} \mathrm{N} \mathrm{m}^{-2} \mathrm{yr}^{-1} ; L_{N C}$ ratio of $\mathrm{N}$ to $\mathrm{C}$ in litterfall material ( $\mathrm{g} \mathrm{N} \mathrm{g}^{-1} \mathrm{C}$ ); $N_{u p}$, maximum ratio of nitrogen immobilized by bacteria to carbon respired ( $\mathrm{g} \mathrm{N}$ immobilized $\mathrm{g}^{-1} \mathrm{C}$ respired); $N_{L O S S}$, specific rate of loss of nitrogen from the soil system ( $\mathrm{g} \mathrm{N}$ lost $\mathrm{g}^{-1} \mathrm{~N}$ in available [labile, mobile] compartment $\mathrm{yr}^{-1}$ ). The parameter $r_{g r f}$ is the fraction of $\left(G P P-R_{m}\right)$ that is assumed to be lost to growth respiration.

Calibration of TERRA. During calibration for each of the 17 vegetation types, the values of the eight parameters for the grid cell model listed above are adjusted to satisfy the conditions that (1) the system is in steady state; (2) the input to the carbon vegetation compartment over one year is equal to observed net primary productivity (NPP) plus total plant respiration (RESPAUTO); (3) total plant respiration equals RESPAUTO; (4) total litterfall equals NPP; (5) total soil respiration equals NPP; (6) total nitrogen lost by the system equals total input $\left(N_{\text {input }}\right)$; (7) total nitrogen taken up over the year equals NUPTAKE; (8) total transfer of nitrogen from plants to soil organic nitrogen equals NUPTAKE; and (9) net mineralization equals NUPTAKE. The initial conditions for the state variables and values of NUPTAKE, NPP, and RESPAUTO for the 17 vegetation types are given by McGuire et al. (1992). During calibration, the grid cell model is run iteratively annually varying the 8 calibration parameters until steady state is achieved.

We have calibrated these eight parameters for the 17 vegetation types using data for GPP, NPP, and NUPTAKE found in McGuire et al (1992). We used values of $N_{\text {input }}$ found in Raich et al. (1991) and Lyons et al. (1990). Data for climatic variables were taken from Muller (1982) and NOAA (1974). Details of the calibration procedure can be found in Kercher et al. (1992). In Table 1, we show the results of the calibration for the eight parameters. The parameters determined in the calibration are in agreement with general notions of ecosystem behavior. The tropical forests stand out with the highest potential productivity $\left(C_{\max }\right)$; next come the temperate forests and tall grasslands, followed by the boreal forests, short grassland, and arid shrublands, i.e., highly stressed systems. Cmax correlates with leaf area index. The effect of other factors on productivity such as length of the growing season, light, temperature, precipitation, and soil moisture are accounted for elsewhere in the model. The value of $K_{r}$, is low for forests, intermediate for woodland, savanna, and shrubland, and high for grassland and tundra. This variation compensates for the simple structure (a single vegetation compartment) of the original TEM local ecosystem model. If we separate out the plant parts into leafy, bole, root components, etc., we should find that $K_{r}$ is similar for similar components. This suggests that a more realistic definition of state variables is an improvement indicated for TERRA. Note that the calibrated values of the litterfall turnover rate $K_{\text {fall }}$. is low for forests, intermediate for woodland, savanna, and tundra, and high for grasslands. That is those systems with perennial woody parts have low values whereas those systems consisting mainly of leafy parts that turn over once a year have high values. This variation also compensates for the single vegetation compartment of the local community model. The polar values and tropical values of $K_{d}$ are relatively low while the temperate systems have relatively high base rates of decomposition. The lowest values of $N_{\max }$ are for polar systems and arid systems; the 
Table 1. The calibrated values of the TERRA model are shown for the 17 vegetation types.

\begin{tabular}{|c|c|c|c|c|c|c|c|c|}
\hline Vegetation class & $\begin{array}{l}C_{\max }\left(10^{4}\right. \\
g_{\left.m^{-2} y^{-1}\right)}\end{array}$ & $\begin{array}{l}K_{r} \\
\left(y^{-1}\right)\end{array}$ & $\begin{array}{l}K_{\text {fall }} \\
\left(y^{-1}\right)\end{array}$ & $\begin{array}{l}K_{d} \\
\left(y^{-1}\right)\end{array}$ & $\begin{array}{l}N_{\max } \\
\left(\mathrm{g} \mathrm{m}^{-2} \mathrm{y}^{-1}\right)\end{array}$ & $\begin{array}{l}L_{N C} \\
\left(10^{-3}\right)\end{array}$ & $N_{u p}$ & $\begin{array}{l}N_{\text {LOSS }} \\
\left(\mathrm{y}^{-1}\right)\end{array}$ \\
\hline $\begin{array}{l}\text { Polar } \\
\text { Desert (1) }\end{array}$ & 1.61 & 0.30 & 0.14 & 0.011 & 2.8 & 7.7 & -0.19 & 0.024 \\
\hline $\begin{array}{l}\text { WetMoist } \\
\text { Tundra (2) }\end{array}$ & 1.73 & 0.30 & 0.16 & 0.0072 & 4.7 & 6.7 & -0.25 & 0.024 \\
\hline $\begin{array}{l}\text { Boreal } \\
\text { Woodland (3) }\end{array}$ & 1.26 & 0.088 & 0.077 & 0.013 & 7.6 & 8.8 & -0.23 & 0.95 \\
\hline $\begin{array}{l}\text { Boreal } \\
\text { Forest (4) }\end{array}$ & 1.40 & 0.024 & 0.024 & 0.019 & 11 & 13 & -0.14 & 0.74 \\
\hline $\begin{array}{l}\text { Temperate } \\
\text { Coniferous } \\
\text { Forest (5) }\end{array}$ & 2.32 & 0.014 & 0.012 & 0.016 & 10 & 7.9 & -0.089 & 0.51 \\
\hline $\begin{array}{l}\text { Arid } \\
\text { Shrubland (6) }\end{array}$ & 0.718 & 0.076 & 0.21 & 0.0044 & 4.3 & 24 & -0.14 & 0.065 \\
\hline $\begin{array}{l}\text { Short } \\
\text { Grassland (7) }\end{array}$ & 1.21 & 0.19 & 0.65 & 0.024 & 4.4 & 17 & -0.67 & 0.45 \\
\hline $\begin{array}{l}\text { Tall } \\
\text { Grassland (8) }\end{array}$ & 2.97 & 0.20 & 0.68 & 0.0082 & 3.9 & 12 & -0.28 & 0.23 \\
\hline $\begin{array}{l}\text { Temperate } \\
\text { Savanna (9) }\end{array}$ & 2.29 & 0.074 & 0.22 & 0.054 & 6.6 & 12 & -1.46 & 0.16 \\
\hline $\begin{array}{l}\text { Temperate } \\
\text { Deciduous } \\
\text { Forest (10) }\end{array}$ & 2.01 & 0.018 & 0.042 & 0.037 & 12 & 12 & -0.36 & 0.23 \\
\hline $\begin{array}{l}\text { Temperate } \\
\text { Mixed } \\
\text { Forest (11) }\end{array}$ & 3.18 & 0.026 & 0.044 & 0.038 & 9.5 & 9.9 & -0.40 & 0.25 \\
\hline $\begin{array}{l}\text { Temperate } \\
\text { Evergreen } \\
\text { Forest }(12)\end{array}$ & 1.88 & 0.024 & 0.048 & 0.037 & 17 & 8.3 & -0.48 & 0.54 \\
\hline $\begin{array}{l}\text { Mediterranean } \\
\text { Shrubland (13) }\end{array}$ & 2.27 & 0.098 & 0.12 & 0.012 & 8.1 & 26 & -0.48 & 0.19 \\
\hline $\begin{array}{l}\text { Tropical } \\
\text { Savanna(14) }\end{array}$ & 2.17 & 0.11 & 0.30 & 0.030 & 14 & 23 & -0.34 & 0.39 \\
\hline $\begin{array}{l}\text { Xeromorphic } \\
\text { Woodland (15) }\end{array}$ & 2.62 & 0.10 & 0.13 & 0.015 & 9.0 & 25 & -0.54 & 0.16 \\
\hline $\begin{array}{l}\text { Tropical } \\
\text { Deciduous } \\
\text { Forest (16) }\end{array}$ & 6.44 & 0.061 & 0.060 & 0.023 & 17 & 38 & -1.86 & 0.90 \\
\hline $\begin{array}{l}\text { Tropical } \\
\text { Evergreen } \\
\text { Forest (17) }\end{array}$ & 5.10 & 0.044 & 0.046 & 0.010 & 16 & 23 & -0.71 & 2.1 \\
\hline
\end{tabular}


Table 2. Total system sensitivity $\left\langle S_{k}\right\rangle$ of the model parameter $k$ of the grid cell cycling model. In this table we show all parameters for which $\left\langle S_{k}\right\rangle>0.2$ for five of the 17 vegetation types. $\left\langle S_{k}\right\rangle$ is defined to represent the average fractional change for all five carbon/nitrogen pools.

\begin{tabular}{|c|c|c|c|c|c|c|c|c|c|}
\hline \multicolumn{2}{|c|}{ Wet/Moist Tundra } & \multicolumn{2}{|c|}{$\begin{array}{l}\text { Temperate Con- } \\
\text { iferous Forest }\end{array}$} & \multicolumn{2}{|c|}{$\begin{array}{l}\text { Temperate Decid- } \\
\text { uous Forest }\end{array}$} & \multicolumn{2}{|c|}{ Tropical Savanna } & \multicolumn{2}{|c|}{$\begin{array}{l}\text { Tropical Evergreen } \\
\text { Forest }\end{array}$} \\
\hline Parameter & $\left\langle s_{k}\right\rangle$ & Parameter & $\left\langle s_{k}\right\rangle$ & Parameter & $\left\langle s_{k}\right\rangle$ & Parameter & $\left\langle S_{k}\right\rangle$ & Parameter & $\left\langle S_{k}\right\rangle$ \\
\hline$M_{o p t}$ & 0.72 & $M_{o p t}$ & 1.33 & $M_{\text {opt }}$ & 1.50 & $M_{o p t}$ & 1.73 & $P V$ & 0.40 \\
\hline$s r$ falb $_{s p}$ & 0.72 & $F C$ & 0.32 & $K_{d}$ & 0.37 & $K_{d}$ & 0.32 & Rootdp & 0.40 \\
\hline$F C$ & 0.58 & $K_{d}$ & 0.30 & $P V$ & 0.35 & $b$ & 0.30 & $F C$ & 0.39 \\
\hline Srfalbwi & 0.58 & $P V$ & 0.27 & Rootdp & 0.35 & $M_{\text {sat }}$ & 0.28 & $\boldsymbol{K}_{\boldsymbol{d}}$ & 0.35 \\
\hline PV & 0.34 & Rootdp & 0.27 & $F C$ & 0.28 & $F C$ & 0.28 & $c_{\max }$ & 0.29 \\
\hline Rootdp & 0.34 & $M_{\text {sat }}$ & 0.26 & $M_{\text {sat }}$ & 0.27 & $P V$ & 0.26 & & \\
\hline$K_{d}$ & 0.26 & $K_{\text {fall }}$ & 0.22 & Nup & 0.26 & Rootdp & 0.23 & & \\
\hline$N_{\text {up }}$ & 0.24 & & & $K_{\text {fall }}$ & 0.24 & $K_{\text {fall }}$ & 0.27 & & \\
\hline$K_{\text {fall }}$ & 0.23 & & & $N_{\max }$ & 0.22 & $T_{o p t}$ & 0.21 & & \\
\hline$V_{C N}$ & 0.20 & & & $C_{\max }$ & 0.20 & & & & \\
\hline$b$ & 0.20 & & & & & & & & \\
\hline
\end{tabular}

Table 3. Change in carbon sequestration $\left(\Delta \mathrm{C}\right.$ in $\left.\mathrm{kg} \mathrm{m}^{-2}\right)$ with a 10 percent increase in each parameter. These entries are for all changes in carbon greater than $0.4 \mathrm{~kg} \mathrm{~m}^{-2}$.

\begin{tabular}{|c|c|c|c|c|c|c|c|c|c|}
\hline \multicolumn{2}{|c|}{ Wet/Moist Tundra } & \multicolumn{2}{|c|}{$\begin{array}{l}\text { Temperate } \\
\text { Coniferous Forest }\end{array}$} & \multicolumn{2}{|c|}{$\begin{array}{l}\text { Temperate } \\
\text { Deciduous Forest }\end{array}$} & \multicolumn{2}{|c|}{ Tropical Savanna } & \multicolumn{2}{|c|}{$\begin{array}{l}\text { Tropical Evergreen } \\
\text { Forest }\end{array}$} \\
\hline Parameter & $\Delta \mathrm{C}$ & Parameter & $\Delta \mathrm{C}$ & Parameter & $\Delta \mathrm{C}$ & Parameter & $\Delta C$ & Parameter & $\Delta \mathrm{C}$ \\
\hline $\bar{M}_{\text {opt }}$ & 2.8 & $M_{o p t}$ & 4.3 & $M_{\text {opt }}$ & 2.6 & $M_{o p t}$ & $3 . .3$ & $\overline{P V}$ & -2.7 \\
\hline$S_{r f a l b}$ sp & 2.8 & $L_{N C}$ & -3.0 & $K_{\text {fall }}$ & -1.1 & $b$ & 0.7 & Rootdp & -2.7 \\
\hline$P V$ & 1.0 & $P V$ & -2.9 & $L_{N C}$ & -1.0 & $K_{d}$ & -0.5 & $F C$ & -2.6 \\
\hline Rootdp & 1.0 & Rootdp & -2.9 & $P V$ & -0.9 & $L_{N C}$ & -0.5 & $C_{\max }$ & 2.4 \\
\hline$K_{d}$ & -0.8 & $K_{\text {fall }}$ & -2.7 & Rootdp & -0.9 & & & $L_{N C}$ & -1.6 \\
\hline \multirow[t]{14}{*}{$C_{\max }$} & 0.6 & $F C$ & -2.1 & $N_{\max }$ & 0.9 & & & $\boldsymbol{K}_{\boldsymbol{r}}$ & -1.2 \\
\hline & & $N_{\max }$ & 1.7 & $C_{\max }$ & 0.8 & & & $K_{d}$ & -1.0 \\
\hline & & $N_{u p}$ & -1.5 & $N_{u p}$ & -0.6 & & & $K_{\text {fall }}$ & -1.0 \\
\hline & & $c_{\max }$ & 1.5 & $F C$ & -0.5 & & & $k_{i}$ & -0.9 \\
\hline & & $K_{r}$ & -1.3 & $k_{c}$ & -0.5 & & & NLOSS & -0.8 \\
\hline & & $k_{n l}$ & -1.3 & & & & & $N_{u p}$ & -0.8 \\
\hline & & $k_{i}$ & -1.3 & & & & & $k_{n l}$ & -0.8 \\
\hline & & $k_{c}$ & -1.2 & & & & & $k_{c}$ & -0.8 \\
\hline & & Cldparl & 1.1 & & & & & $N_{\max }$ & 0.7 \\
\hline & & $T_{o p t}$ & -1.1 & & & & & $a$ & 0.7 \\
\hline & & $\min$ & 1.0 & & & & & $\alpha$ & 0.5 \\
\hline & & $M_{\text {sat }}$ & 0.7 & & & & & & \\
\hline & & $V_{C N}$ & 0.7 & & & & & & \\
\hline & & $L A I_{\max }$ & -0.7 & & & & & & \\
\hline
\end{tabular}


highest values are for tropical forests (and temperate evergreens) with the rest of the temperate systems and boreal systems at intermediate to high values. The highest ratios of litter $\mathrm{N}$ to litter $\mathrm{C}$ of $L_{N C}$ are in the tropics and the lowest values are in the polar and boreal regions. The values of $N_{\text {LOSS }}$ reflect the data values taken from the literature and used for the calibration input. They correspond closely with the input values.

TERRA will be recalibrated as model improvements are made. We anticipate modifications to DAYTRANS transpiration calculations and other portions of TERRA including soil and vegetation processes. The areas needing modifications are described in some detail below in the FY94 section of this report.

Sensitivity Analysis of Total System Response of Grid Model. We have examined the sensitivity of the grid-cell model for each of the 17 vegetation types to changes in the model parameters. We first ran the model with each parameter set to its nominal value. Then, one by one, we increased each parameter by $10 \%$ and $50 \%$ and ran the model to steady state to determine the new output values. In this paper, we report only on the results of calculation for the $10 \%$ increase in parameter values.

We define the sensitivity $S_{i k}$ of the state variable $i$ to the parameter $p_{k}$ by

$$
S_{i k}=\frac{\frac{y_{i}\left(\left\{p_{l, \text { qooninal }}, p_{k, \text { new }}\right\}\right)-y_{i}\left(\left\{p_{l, \text { nominal }}\right\}\right)}{y_{i}\left(\left\{p_{l, \text { nominal }}\right\}\right)}}{\frac{p_{k, \text { new }}-p_{k, \text { nominal }}}{p_{k, \text { nominal }}}}
$$

For $\left|S_{i k}\right| \approx 1$ or $\left|S_{i k}\right|>1$, we consider the variable $k$ to be sensitive to parameter $i$ and, speaking colloquially, we refer to the parameter as sensitive. For $\left|S_{i k}\right|<0.1$, we consider the variable to be insensitive. To get an indication of the sensitivity of the system as a whole to the parameter $p_{k}$, we define

$$
\left\langle S_{k}\right\rangle=\frac{1}{5}\left[\sum_{i=1}^{5} S_{i k}^{2}\right]^{1 / 2}
$$

In Table 2, we show $\left\langle S_{k}\right\rangle$ for which $\left\langle S_{k}\right\rangle>0.2$ for five vegetation types. In Table 2, Rootdp is the root depth (m) for the soil texture class and vegetation class with values from Vorosmarty et al. (1989). $P V$ is the pore volume as the fraction of soil volume for the soil texture class as found using data from Vorosmarty et al. (1989) and Raich et al. (1991). $L A I_{\max }$ is the maximum leaf area index for the vegetation class. Data for $L A I_{\max }$ were taken from Dickinson (1986) and Larcher (1980). Srfalb $b_{s p}$ and $S r f a l b_{w i}$ are the albedos for spring and winter, respectively. The data for albedos are taken from Matthew's (1984). All other parameters in Table 2 are defined and their values given in Raich et al. (1991).

$M_{o p t}$ is the value of soil moisture at which soil respiration is maximum. Note that $M_{\text {opt }}$ is the most important parameter for four out of the five vegetation types in Table 2. It appears in an exponent of the function giving soil respiration, hence the extreme sensitivity of the model to this parameter. Soil respiration affects both carbon and nitrogen content of the soil. Albedo is important in the northernmost systems only. Albedo enters into the model by affecting the radiation balance that determines transpiration and ultimately soil moisture. $P V$, Rootdp and $F C$ affect soil moisture content. They have similar $\langle S\rangle$ values across the five systems. For the non-tundra systems, the other system sensitivities are less than 0.4 except for $M_{o p t}$. The decomposition rate parameter $K_{d}$ is a moderately sensitive parameter across all five systems. This is because of its effect on soil organic content. 
Transfers into the soils $\left(K_{\text {fall }}\right)$ for the two temperate forest are also moderately sensitive parameters. To have moderately high $\langle S\rangle$ values, a parameter usually has to affect levels in all or most of the carbon and nitrogen pools. Litterfall rate, $K_{\text {fall }}$, which appears in four system in Table 2, and soil moisture saturation level, $\boldsymbol{M}_{\text {sat }}$, which appears in three system, have the property of affecting both carbon and nitrogen pools. Some parameters only appear once above the cutoff level: $\mathrm{C}: \mathrm{N}$ ratio of vegetation $V_{C N}$ in tundra, albedo only in tundra, $N_{\max }$ only in temperate deciduous forest, and temperature of maximum $\mathrm{CO}_{2}$ assimilation $T_{o p t}$ in tropical savanna.

The total system sensitivity analyses will be repeated after model recalibrations.

Sensitivity of Total Carbon Sequestration of the Grid Model. As part of our sensitivity analysis, we calculate the change in the total carbon content of the system $\left(y_{1}+y_{2}\right)$ as each parameter is increased by $10 \%$. The results of this calculation are shown for the five vegetation types in Table 3 with the results given in $\mathrm{kg} \mathrm{m}^{-2}$. The parameter $\alpha$ is a proportionality constant used in calculating diffuse radiation from the solar constant, absorption of the solar beam, solar altitude, and direct radiation. The value for this parameter is from Turton (1986). Cldparl is the percent of total radiation as PAR at 100\% cloud cover. Values for this parameter is given in Raich et al. (1991). All other parameters in Table 3 are defined above or in Raich et al. (1991).

Note that an increase in $K_{d}$ decreases total carbon sequestration above the cutoff level in three systems of the five. In these systems, an increase in $K_{d}$ respires more carbon from the soil, giving a net loss of carbon. Increasing $P V, \operatorname{Rootdp}$, and $F C$ cause a decrease in soil carbon greater than $0.4 \mathrm{~kg} \mathrm{~m}^{-2}$ in three out of five system due to a loss in soil carbon coming from increased respiration. This increased respiration is due to the change in soil moisture coming from increased soil water capacity. Tundra shows a net increase of carbon due to an increase in soil carbon from a decrease in soil respiraticin îrom the change in soil moisture as $P V$ and Rootdp increase. Not surprisingly, an increase in the gross productivity rate $C_{\max }$ increases carbon sequestering. Also increasing the nitrogen uptake rate of plants $\left(N_{\max }\right)$ has a similar effect. Increasing the litterfall rate $K_{\text {fall }}$ decreases total carbon sequestered. The parameters $k_{i}$ and $k_{c}$ are the half-maxinum levels of GPP for light and atmospheric $\mathrm{CO}_{2}$, respectively. Increasing either parameter decreases carbon content of the system.

The two systems with relatively small biomass carrying capacity (tundra and savanna) have relatively few parameters causing changes above the cutoff of $0.4 \mathrm{~kg} \mathrm{~m}^{-2}$. The forest systems with larger biomass have more parameters affecting changes above the cutoff level. Increasing microbial immobilization in the forest systems $\left(N_{\text {up }}\right)$ decreases stored carbon. Increasing the rate of nitrogen loss from the system ( $\left.N_{L O S S}\right)$ for the tropical forest result in a decrease in carbon pools. An increase in the $\mathrm{C}: \mathrm{N}$ ratio for litterfall $\left(L_{N C}\right)$ for all three forests and tropical savanna produces a substantial loss of carbon from the systems. This effect is mediated by a correcting change in the $y_{6}$ variable to maintain the C:N ratio in vegetation. Note the idiosyncrasies among sensitivities of the different systems. For example, increasing plant respiration $K_{r}$ produces substantial losses of carbon for both temperate coniferous forests and tropical evergreen forests but not for temperate deciduous forests. Another example is that the parameter $b$, which determines leaf area index from actual evapotranspiration, is important for tropical savannas and for no other system.

The sensitivity analysis of carbon sequestration will be repeated after future recalibrations.

Development of the Model of Vegetation Response to Climate (HABITA T). We have begun a program of development of models of the response of vegetation to climate. That is, we assume that environmental variables, mrincipally, climate in conjunction with soil properties, determine the vegetation life forms growing in any specific locality. In this program of model development, we will proceed in four stages: 
(1) investigation of existing methods of determination of vegetation type; (2) development of static, rule-based or statistical classification schemes; (3) development of physiologically-based classification schemes; and (4) development of fully dynamic models of production, succession, dieback, and invasion. Neilson et al. (1992) have developed a rule-based biome model for temperate ecosystems. Woodward (1987) suggested a physiological approach to study vegetation distribution. The dynamical model will be based on extensions of past forest modeling approaches (Botkin et al. 1972, Kercher and Axelrod 1984, and Kercher et al. 1988). In this paper, we report on an investigation in stage 1. Many authors (e.g., Box 1981, Reed and Waring 1974, Woodward 1987) have suggested that actual and potential evapotranspiration variables are more closely related to the correct biological variables determining vegetation response to climate than simple climatic variables such as temperature and precipitation. However, we will first investigate the variables introduced by Holdridge (1967) before moving on to more biologically realistic variables.

Holdridge $(1947,1967)$ assumed that the differentiation and physiognomy of vegetation under natural conditions are so highly correlated to climatic conditions that a complete classification of vegetation can be accomplished by an appropriate classification of climate. His classification of climate is based on two variables: biotemperature and mean annual precipitation. The biotemperature is similar to growing degree days, and is defined as the mean monthly temperature of all monthly temperatures greater than zero degrees Celsius. Holdridge defines a life zone as a convex set of points in the biotemperaturerainfall plane (this plane uses 60 degree tilted axes and a logarithmic scale) with a hexagonal boundary. A graph of the Holdridge life zones has a honeycomb appearance- a contiguous set of non-overlapping hexagonal cells. By construction, the Holdridge method gives a perfect correlation between climate and vegetation, each type of vegetation would belong to one and only one life zone. Whittaker (1975) has suggested a similar 2dimensional plane for specifying vegetation biogeography.

It is instructive to look at the Holdridge system of life zones from the point of view of statistical classification theory. Let $\Omega=\left\{\omega_{1}, \ldots \omega_{N}\right\}$ be the finite set of $N$ vegetation classifications (Holdridge has $N=39$ ). Let $Z_{k}$ be a convex subset of the environmental plane (biotemperature and total annual rainfall), and $\mathbf{x}$ be a point in the environmental plane. For the Holdridge system, $x$ consists of two components: $x_{1}=$ biotemperature and $x_{2}=$ total annual rainfall. The probability that the vegetation type $v$ at a particular land point on the surface of the earth will be classified as $\omega_{k}$, given that the climate $\mathbf{x}$ at that point is a member of subset $Z_{k}$ is given by a straightforward application of Bayes formula:

$$
P\left(v=\omega_{k} \mid \mathrm{x} \in Z_{k}\right)=\frac{P\left(\mathrm{x} \in Z_{k} \mid v=\omega_{k}\right) P\left(v=\omega_{k}\right)}{P\left(\mathrm{x} \in Z_{k}\right)}
$$

where $P(a)$ is the probability that $a$ is true and $P(a \mid b)$ is the probability that $a$ is true given that $b$ is true. The convex sets $Z_{k}$ in the Holdridge system are hexagons, and in its simplest form the Holdridge system requires that:

$$
P\left(v=\omega_{k} \mid \mathbf{x} \in Z_{k}\right)=1
$$

and

$$
P\left(\mathbf{x} \in Z_{k} \mid v=\omega_{k}\right)=1
$$

Equation $9 \mathrm{a}$ is the condition that all the points whose climate belongs to a particular hexagon $Z_{k}$ must have vegetation of type $\omega_{k}$. That is, all the points inside a climate 
hexagon must map to only one vegetation type. Likewise, eq. $9 \mathrm{~b}$ enforces that all places on earth that have vegetation type $\omega_{k}$ must have climate of type $Z_{k}$. That is, all vegetation of type $\omega_{k}$ must map to inside the climate hexagon $Z_{k}$. Combining eqs. 8, 9a, and $9 b$, we find

$$
P\left(v=\omega_{k}\right)=P\left(\mathbf{x} \in Z_{k}\right)
$$

under the Holdridge assumptions and we see that a given vegetation type occurs oniy as frequently as the set of climatic conditions defined by the corresponding life zone.

Note that for any classification scheme, in the absence of any climatic information the best prediction one can make for $\omega_{k}$ is that $\omega_{k}$ with the maximum probability. Therefore an essential property of any classification/prediction of vegetation from climate must be:

$$
P\left(v=\omega_{k} \mid \mathrm{x} \in Z_{k}\right) \gg P\left(v=\omega_{k}\right)
$$

Furthermore, the subsets $Z_{k}$ should be disjoint and span the environmental space.

We can test how well the Holdridge variables, biotemperature and total annual rainfall (on a logarithmic scale) meet these essential properties by using the global data sets of vegetation classification (Matthew's 1983) and of mean monthly temperature and mean monthly precipitation (Leemans and Cramer 1990). This exercise is described in the next section. We emphasize that we are not testing the Holdridge approach per se, because in its simplest form the Holdridge approach classifies climate. Rather we are asking whether or not this climate classification scheme uniquely predicts vegetation classes.

Vegetation Types in the Holdridge Plane. We extracted the Matthew's and the Leemans and Cramer data sets from a large global data base (NGDC 1991). The vegetation data are gridded on $\mathrm{a} 1^{\circ} \times 1^{\circ}$ grid and are developed from vegetation maps collected from authorities over the globe. Leemans and Cramer (1990) produced $0.5^{\circ} \mathrm{X}$ $0.5^{\circ}$ gridded data from individual weather station data that were averaged over 20-30 years and then interpolated to the grid over the continents. After extraction of the datasets from the NGDC databases, we entered the data into the S programming environment (Becker et al. 1988) for data analysis in which all manipulations and analyses reported below were done. We take each grid cell to be one data point. We first plotted the box plots (Tukey 1977) of the interquartile range and total range for all 30 vegetation types for both the mean of the monthly temperatures greater than $0^{\circ} \mathrm{C}$ (Holdridge biotemperature or BT) and total annual precipitation (TAP). There was substantial overlap of the interquartile ranges for both variables. We next considered the positions of the vegetation clusters in the Holdridge plane (BT-TAP plane). We used the convex hull approach for this analysis (Efron 1965, Barnett 1976, Bebbington 1978). The outermost convex hull is the outermost set of points that when connected form a convex polygon (no "dents"). Inside this outer hull, there is another hull and inside this hull is yet another, just like the peels of an onion. In fact trimming convex hulls from a data cluster is sometimes referred to as "peeling". To show the center or modal point of each cluster for a vegetation type, we peel all convex hulls down to the last or innermost hull and take the average of the points in this hull. These centers for the 30 vegetation types of Matthew's in the Holdridge plane are shown in Fig. 1a. It appears from this diagram that the two Holdridge variables may be able to discriminate between vegetation types. To test this, we need to plot the outer boundaries of the clusters and examine them for overlap. 

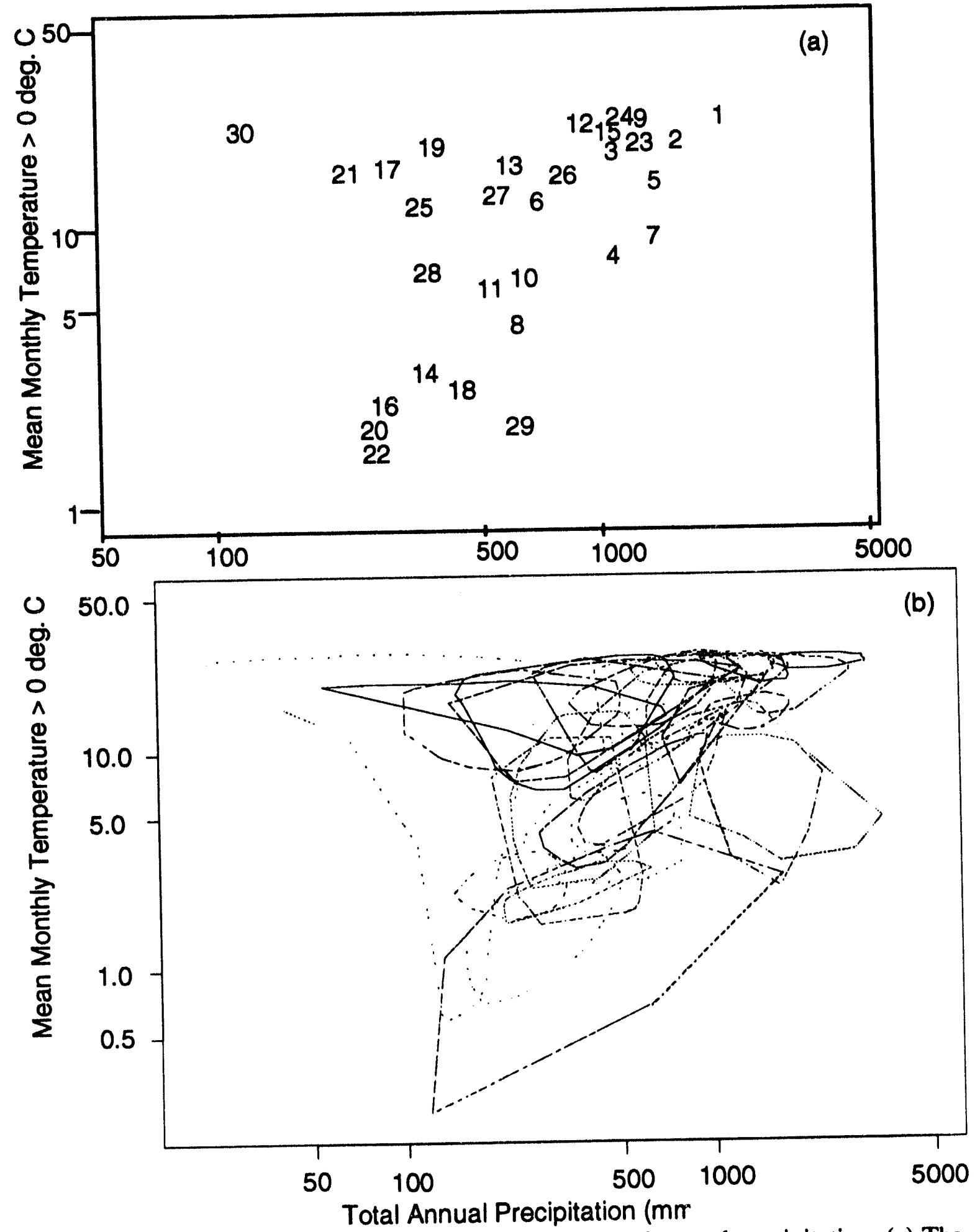

Figure 1. The Holdridge plane of biotemperature and total annual precipitation. (a) The innermost hull centers are plotted. (b) The plots of the 50th-percentile hulls of the 30 vegetation types of Matthews (1983). 
We found some examples of outlier contamination of the data when we examined plots of the convex hulls. To eliminate outliers, we investigated two schemes of discarding convex hulls: one using the density of points per unit area in the Holdridge variable plane and the other using the area of the convex hull peels. However, there was no consistent pattern produced by these methods upon which to base a criteria of trimming outliers by discarding hulls. Instead, we used a conservative approach to present the data consisting of generalizing the interquartile range that is used in boxplots. In boxplot diagrams, only those data points lying between the 25th and 75th percentile are in the box. Data points lying outside these quartiles, i.e., $50 \%$ of the data, are outside the box. The generalization of the box from 1-dimension to 2-dimensions is the convex hull such that $50 \%$ of the data points lie on or within the hull. The other half of the data is outside this particular hull, which we refer to as the 50th-percentile hull. The 50th-percentile hulls are a very conservative representation of the data in that half of the data are discarded, thus removing the outliers. If the resulting 50th-percentile hulls have clear and substantial overlap, it indicates that the variables in that two dimensional space will not discriminate between the clusters. In Fig. 1b, we plot the 50th-percentile hulls in the Holdridge plane for the $\mathbf{3 0}$ vegetation types of Matthew's. We see that there is substantial overlam of the 50thpercentile hulls in Fig. 1b. We therefore conclude that the two Holdridge variables are irsufficient to discriminate between the 30 vegetation types of Matthew's. We expect that the information contained in the distribution of temperature and precipitation throughout the year and their correlations will also be needed to separate these clusters; in addition, monthly actual and potential evapotranspiration may also be needed to achieve separation.

\section{Progress From October 1992 to September 1993}

Global Terrestrial Productivity and Biogeochemical Cycling Model Development and Preliminary Calculations. During FY93, we completed implementation of the full global model of TERRA. The global version was implemented on a $1^{\circ} \times 1^{\circ}$ grid covering the Earth's land surface. The local site model is executed within each grid cell. There are two versions of the global TERRA model: one operating at a daily time step and one operating at a monthly time step.

The global model requires inputs of vegetation type, average monthly temperature, monthly precipitation, average daily maximum temperature for the each month, average daily minimum temperature for each month, relative humidity or dew point, cloudiness, $\mathrm{CO}_{2}$ concentration, nitrogen deposition, and soil texture class. From these variables and the latitude of each grid cell, other variables such as PAR or net radiation are calculated.

For the vegetation-type data, we currently use the vegetation-type data set of Matthews (1983) for setting the vegetation type within each grid cell. Eventually HABITAT will supply this information to TERRA. The determination of vegetation type then fixes the parameters of the generic model for each grid cell. The Matthew's data set is based on a 30-member aggregated set that covers the types set by UNESCO. TERRA transforms the 30 types of Matthews onto 17 ecosystem types. For the environmental variable of average monthly temperature, monthly cloudiness, and average monthly precipitation, we use the gridded data sets of Leemans and Cramer (1990). For the soil texture class data, we use the gridded global data base of Zobler (Staub and Rosenzweig 1987). All of these data bases are found in NGDC (1991). During FY93, all these data bases were accessed and data reformatted to be suitable for input into the global version of TERRA.

No gridded data bases exist for the other remaining data inputs to TERRA. During FY93, we began an effort to develop our own globally gridded data bases for these input needs. See below for progress on this effort. While this effort to rigorously develop gridded data bases from actual station data was ongoing, we have created artificial strawmen data bases as a temporary measure to allow us to proceed with development of 
the global version of TERRA and to explore the properties of TERRA. Strawmen data bases for average daily maximum and minimum temperatures for each month were created from the monthly average temperature data base by adding or subtracting the appropriate amount found by averaging these differences for a selected subset of station data. An estimate for the dewpoint was taken to be the average daily minimum. The number of days with rain per month were estimated by reviewing selected station data. Nitrogen inputs were estimated on a biome basis using the nitrogen inputs for the calibration sites. After full implementation of CERES, nitrogen inputs for TERRA will be from deposition calculations made by the atmospheric chemistry and transport model.

During FY93, we made a trial calculation of the global model of TERRA. TERRA was run to steady state in a stand alone calculation with data file inputs. The annual global net primary production (NPP = gross primary production - plant respiration) calculated by TERRA was 52.0 gigatons $\mathrm{C} \mathrm{yr}^{-1}$. This compares favorably with the value of $\mathbf{5 3 . 2}$ gigatons $\mathrm{C} \mathrm{yr}^{-1}$ calculated by Melillo et al. (1993) using TEM. TERRA calculates several fluxes and pools that can be compared to other calculations or measurements. For example, the calculation of actual evapotranspiration (AET) generally agrees with previous calculations of AET over large land areas [i.e. Geiger (1965) as cited by Leith (1975)], although some discrepancies occur which seem to be attributable to the details of the vegetation data base used by TERRA. TERRA calculations also show high levels of organic carbon in tropical soils and in high latitude or tundra and boreal soils. This latter result is consistent with the concern that there exists a potential for significant releases of carbon from high latitude soils due to rising temperatures in the high latitudes.

In Fig. 2, we show the net primary productivity $(\mathrm{g} \mathrm{m}-2)$ calculated by TERRA for January, April, Iuly, and October. The top figures contain the NPP results from TERRA and the boitom figures are the normalized difference vegetation index (NDVI) derived from Advanced Very High Resolution Radiometer (AVHRR) data from NOAA Polar Orbiting Environmental Satellites. NDVI is calculated by

$$
N D V I=350\left(\frac{c_{2}-c_{1}}{c_{2}+c_{1}}+0.05\right)+15
$$

where $c_{1}$ is the signal received by AVHRR in the visible band $(0.58$ to $0.68 \mu \mathrm{m})$ and $c_{2}$ is the signal in the infrared band $(0.73$ to $1.10 \mu \mathrm{m})$. Chlorophyll has more than three times the reflectance in the infrared as in the visible region of the spectrum. The level of NDVI is an indication of foliage LAI. NDVI and NPP have been shown to be correlated within regions. However, no correlation has been shown c sross biomes or at global scales. Instead, we use the comparison of NDVI and NPP as an indication or flag for the need of further study. For example, if the estimated NPP (TERRA output) is very high in areas of low foliage (NDVI), this may indicate either that the potential vegetation assumed in TERRA is inconsistent with actual land use practices, an error in the response of the model to stress, or a misclassification of vegetation type. If, on the other hand, foliage is observed in areas with very low estimated NPP, then either there may be an error in the algorithm TERRA uses for calculating leaf area index, an error in the algorithm for the response of productivity to stress, an error in the land use (or vegetation type) classification or some land areas may exhibit moderate levels of foliage yet have low productivity. In comparing the NPP and NDVI shown in Fig 2, one should also bear in mind that the NPP calculations for TERRA are based on 30-year climatic averages and is for potential (preindustrial) vegetation whereas the AVHRR satellite date are values for 1986 and reflect actual land use conditions on the ground. Even with these differences in mind striking parallels in patterns do occur. For example the north-south movement of "greenness" of the Sahel in Africa is tracked over the year The gross patterns of predicted productivity and NDVI for the northern hemisphere temperate, boreal, and tundra systems are also similar. 


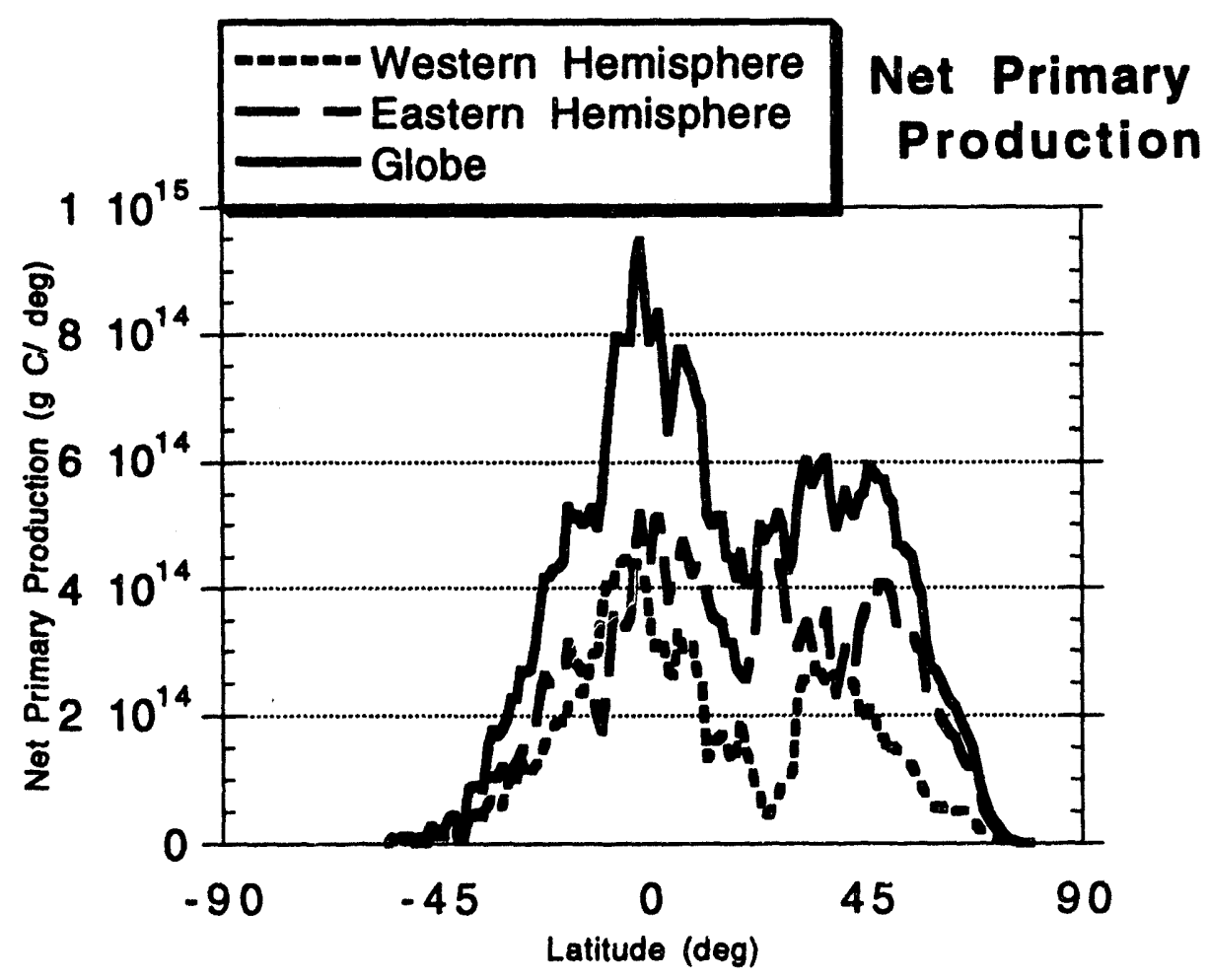

Figure 3. Net primary productivity for the western hemisphere, eastern hemisphere, and globe. Values have been found by summing productivity over all longitude between degrees of latitude.

On the other hand, anomalous conditions in southeast Asia (India, Burma, Thailand, China, Indonesia, and Australia) suggest land use is important to match patterns. In these areas, we must also examine the phenology of vegetation processes and the stress response functions.

In Fig. 3, we show total net primary production plotted against latitude. For this figure, we have summed the terrestrial productivity over longitude between each degree of latitude. This plot shows the equatorial peak in productivity. The relative size of net primary production in the western hemisphere and eastern hemisphere north of the equator reflects the difference in size of North America and the Eurasian land mass. NPP for the northeast, southeast, northwest, and southwest quadrants were 22.6, 9.0, 11,5, and 8.7, respectively. For NPP vs latitude, there is a peak value for NPP of $0.95 \mathrm{Gt} \mathrm{C} \mathrm{yr}^{-1} \mathrm{deg}^{-1}$ in the tropics while northern temperate zone values are between 0.45 and 0.6 .

Gridding Climatic Data and HABITAT Development. Globally gridded climatic data bases are necessary for HABITAT development to follow the program laid out above. Consequently, an effort was begun in FY93 to grid, i.e., interpolate on a grid, the station data for the various climatic variables that cannot be found in gridded form such as dew point, average maximum and minimum daily temperature for the month, etc. We use the Hardy multiquartic method of interpolation for the gridding procedure. This problem was found to be extremely difficult because of (1) the large number of stations resulted in the need to invert a large dimensional matrix and (2) the high density of stations in certain land areas produce local problems of ill-conditioning. However, a procedure was designed to overcome these obstacles by suitable rescaling and domain decomposition. This effort carried over into FY94.

Soil Processes, CENTURY, and DNDC. We began work on improving the soil submodel in FY93. During FY93 we acquired CENTURY (Parton et al. 1987), a 
model of soil processes, particularly organic matter decomposition, and DNDC (Li 1991), a model of soil nitrogen dynamics. We examined the approaches used by CENTURY and DNDC for the respective processes that they simulate and developed a plan for implementing improvements in DNDC and incorporating DNDC and CENTURY into TERRA. The original design of DNDC was to operate over a short time span (about 1 year) and the passive soil organic matter (SOM) pool does not interact with the active SOM phases. This causes decomposing plant residues to accumulate in the passive organic phase. Because TERRA will operate over longer time spans (greater than 50 years), we must account for interactions between active and passive phases. CENTURY accounts for these interactions, and the SOM components of CENTURY will be used in TERRA instead of DNDC's. To incorporate DNDC into TERRA, we will correct errors in DNDC first. For example, after a rainfall event the denitrification portion of DNDC runs while the water-filled-pore-space (WFPS) of the soil is greater than $40 \%$ for a total of ten days. This means that in areas where rainfall events exceed 36 per year, the denitrification submodel executes for more than 365 days. Another example is that $\mathrm{Li}(1991)$ chose $40 \%$ WFPS as the transition point from aerobic to anaerobic soil conditions, whereas there is considerable evidence that $60 \%$ WFPS is the critical transition point from aerobic to anaerobic processes (Davidson 1993). Also, there is no direct effect of moisture on the denitrification reduction sequence in DNDC. Observations show that as soil moisture increases beyond field capacity and oxygen diffusion is impeded, denitrification processes initially favor relatively oxidized compounds such as NO. As water content increases still further, however, oxygen diffusion decreases more and the end products contain larger percentages of $\mathrm{N}_{2} \mathrm{O}$ and $\mathrm{N}_{2}$. However, in DNDC the ratio of $\mathrm{NO}$ and $\mathrm{N}_{2} \mathrm{O}$ in the end products is not affected by the degree of saturation. We will account for these effects by adjusting the aerobic-toanaerobic threshold should be set at $60 \%$ and introducing a moisture parameter in the reduction sequence. We will also correct the way the water submodel of DNDC initializes after rain events. The modified DNDC will be tested against field data.

\section{Expected Progress From October 1993 to September 1994}

Global Terrestrial Productivity and Biogeochemical Cycling Model Development and Preliminary Calculations. To date in FY94, we have examined the net ecosystem productivity (gross primary productivity - plant respiration - soil respiration) (NEP) for the terrestrial biosphere of the trial calculation. In Fig. 4, we show seasonal amplitude of terrestrial NEP plotted against latitude. For this calculation, we sum terrestrial NEP over longitude for each degree of latitude and then plot the difference between the monthly maximum NEP and monthly minimum. Unlike the peak near the equator that NPP shows in Fig. 3, the seasonal amplitude of terrestrial NEP shows a minimum near the equator. This is because of the absence of seasonality near the equator and the near balance each month between carbon fixation and carbon respiration for the steady state condition. The large northern hemisphere land masses and relatively small southern hemisphere land masses are evident in the figure. The maximum seasonal amplitude of net ecosystem production (NEP) has a minimum of $0.009 \mathrm{Gt} \mathrm{C} \mathrm{mo}^{-1} \mathrm{deg}^{-1} \mathrm{at}$ $1^{\circ}$ to $2^{\circ} \mathrm{N}$ reflecting low tropical seasonality while temperate zone amplitudes range between 0.038 to 0.058 . The highest values $(0.062$ to 0.066$)$ occur in the subtropics. In Fig. 5, we plot $5^{\circ}$ latitude aggregates of terrestrial NEP (summed over all longitudes) over the course of the year. Figs. $5 \mathrm{a}, 5 \mathrm{~b}, 5 \mathrm{c}$, and $5 \mathrm{~d}$ contain the $5^{\circ}$ latitude "bins" from $90^{\circ} \mathrm{N}$ to $45^{\circ} \mathrm{N}$, from $45^{\circ} \mathrm{N}$ to the equator, from the equator to $45^{\circ} \mathrm{S}$, and from $45^{\circ} \mathrm{S}$ to $90^{\circ} \mathrm{S}$, respectively. The data in these graphs are also plotted as a surface plot in Fig. 5e. Note that the northern hemisphere high latitude systems net primary production is heat and light limited and NEP is maximum in the middle of summer. As we move south, the systems 


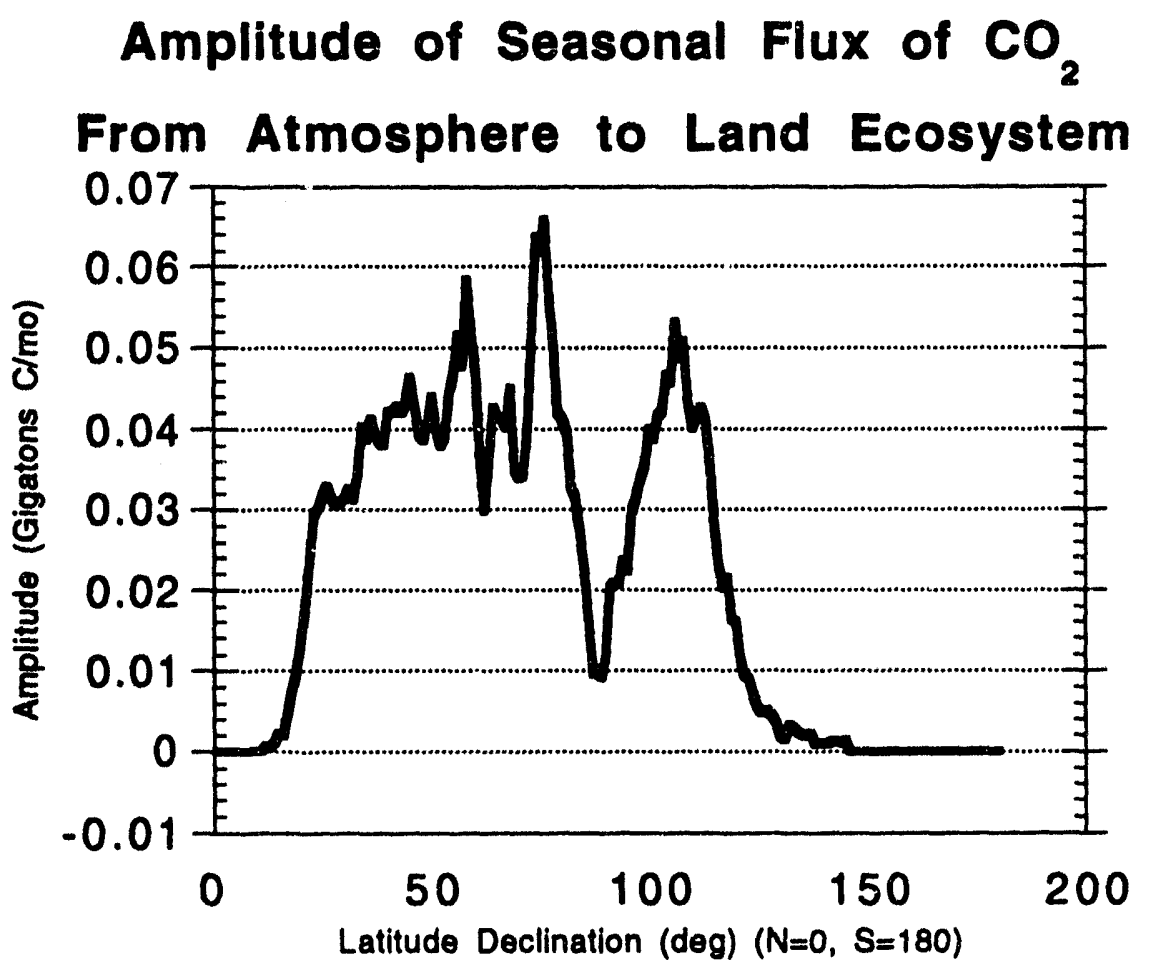

Fig. 4. Seasonal amplitude of net ecosystem production (gross production - plant respiration - soil respiration) plotted against latitude. The horizontal axis is in degrees measured from the North Pole. Note the minimum amplitude at the equator.

become more limited by precipitation and net primary production shifts accordingly. Simultaneously, as we move south soil respiration respond to temperature increases and soil respiration also increases with temperature and with moister seasons of the year. These effects combine to shift the NEP peak earlier in the year in the temperate systems. For the subtropics to the tropics in the northern hemisphere, a late season peak in NEP emerges (September to October). This peak sharply falls off as we approach the equator. TERRA output NEP has been used for input to the GRANTOUR atmospheric chemistry and transport model. Good agreement is obtained for the seasonal dynamics of atmospheric $\mathrm{CO}_{2}$ for stations in Scandinavia and Australia. For the Mauna Loa data, we have good agreement late in the year. However the Mauna Loa data shows a peak concentration in May whereas GRANTOUR/TERRA results show a peak $\mathrm{CO}_{2}$ concentration in January. It is possible that subtropical and tropical land use practices may produce this discrepancy. We will be exploring this possibility for the balance of FY94.

Gridding Climatic Data and HABITAT Development. During FY94, we have completed development of a procedure to carry out the use of the Hardy Multiquartic technique for interpolation and gridding of global climatic data from station data. This procedure had to divide the land surface up into regions to overcome the problem of inversion of large matrices and the ill-conditioning caused by the high density of stations in some areas. The procedure is being automated now. During the balance of FY94, the Hardy Multiquartic procedure will be used to grid the data sets monthly windspeed, average daily maximum and minimum for each month, monthly dew point, monthly relative humidity, and monthly number of days with rainfall. From these data, gridded data sets will be created of monthly potential evapotranspiration and actual evapotranspiration. These data sets will be used to create a rule-based model for the response of vegetation to climate by making use of the regression classification tree technique. 


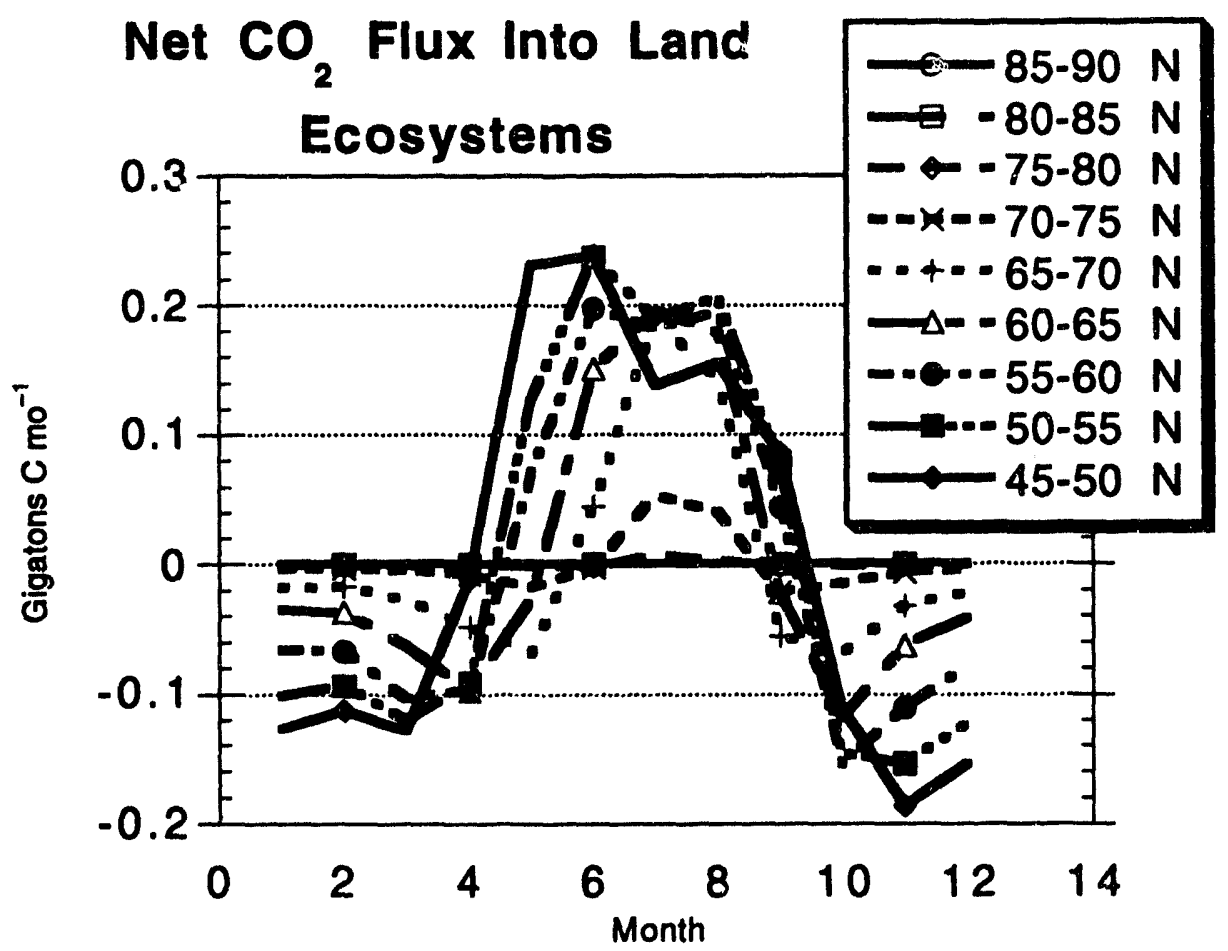

Figure 5a. Net ecosystem production (net $\mathrm{CO}_{2}$ flux into the land surface) during the year for $90^{\circ} \mathrm{N}$ to $45^{\circ} \mathrm{N}$ in $5^{\circ}$ latitude increments.

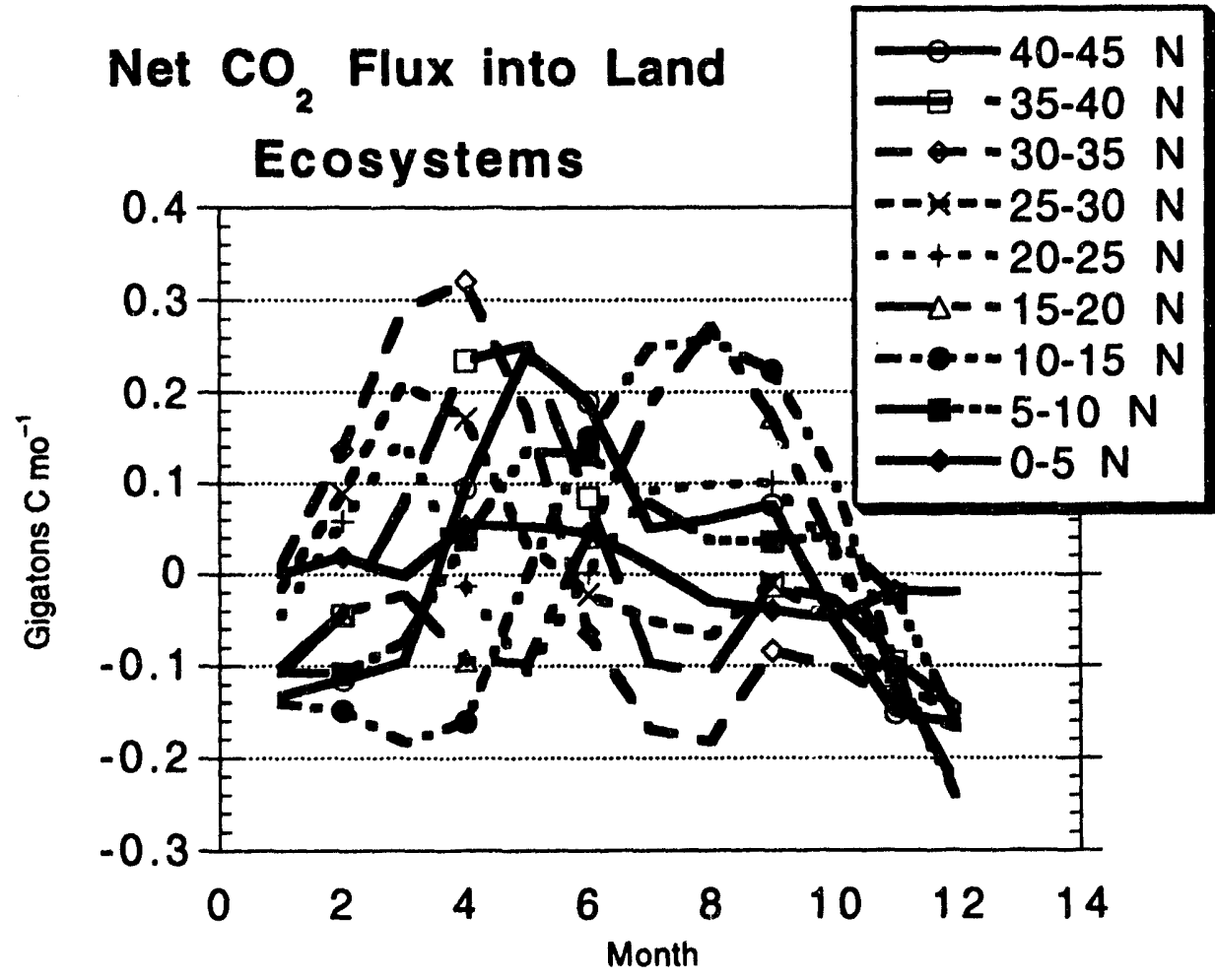

Figure 5b. Net ecosystem production (net $\mathrm{CO}_{2}$ flux into the land surface) during the year for $45^{\circ} \mathrm{N}$ to the equator in $5^{\circ}$ latitude increments. 


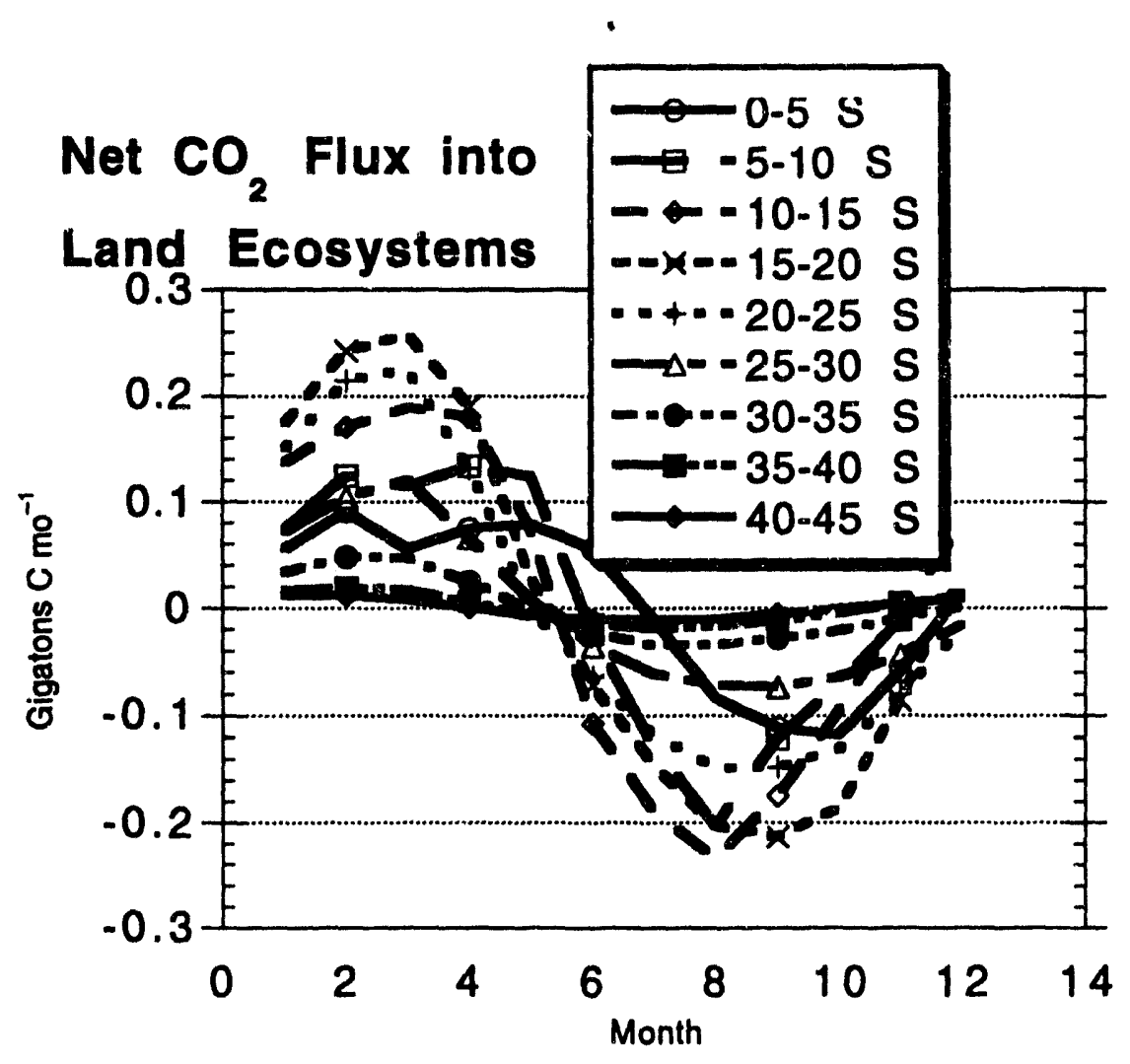

Figure 5c. Net ecosystem production (net $\mathrm{CO}_{2}$ flux into the land surface) during the year from the equator to $45^{\circ} \mathrm{S}$ in $5^{\circ}$ latitude increments.

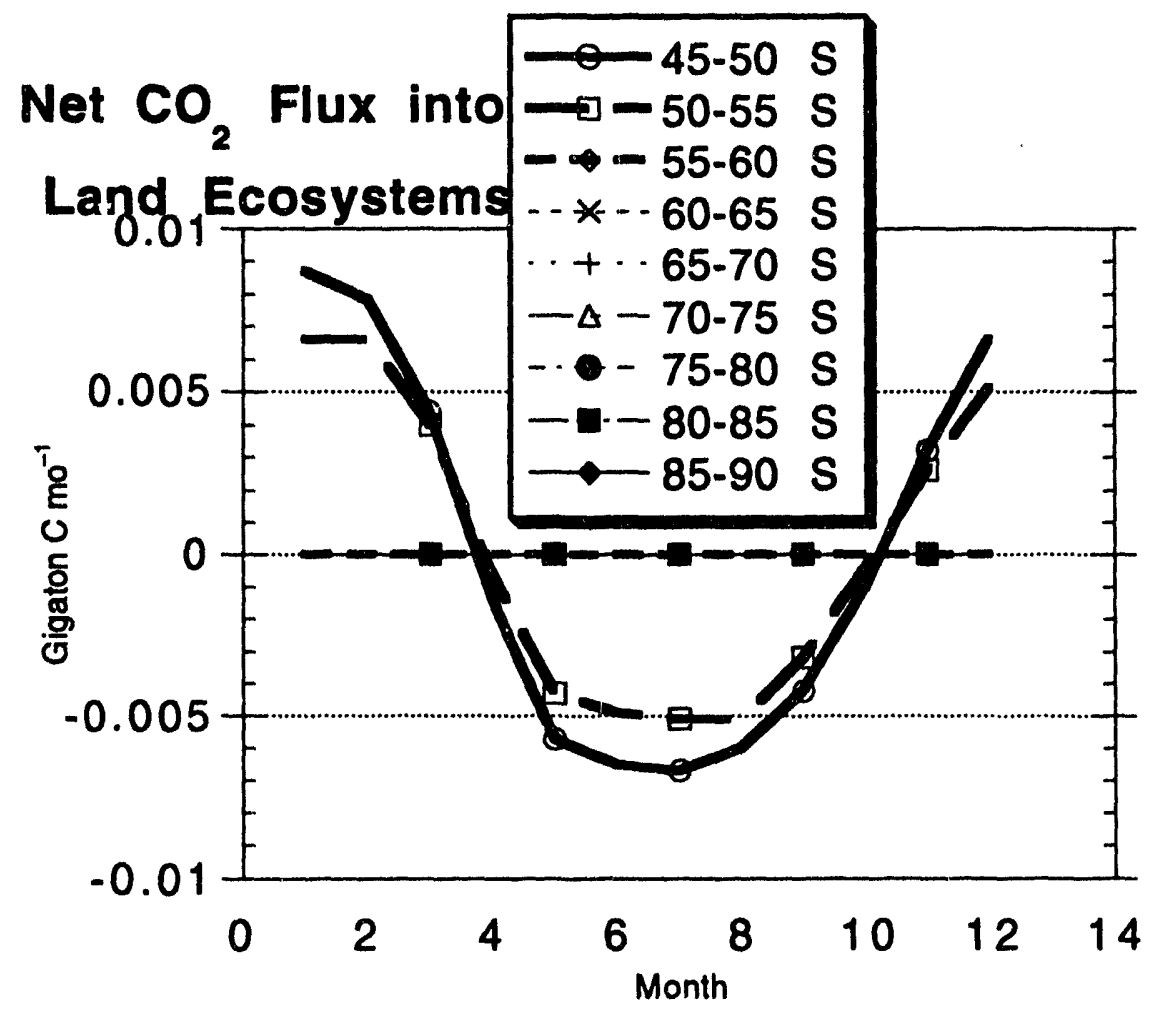

Figure 5d. Net ecosystem production (net $\mathrm{CO}_{2}$ flux into the land surface) during the year from $45^{\circ} \mathrm{S}$ to $90^{\circ} \mathrm{S}$ in $5^{\circ}$ latitude increments. 


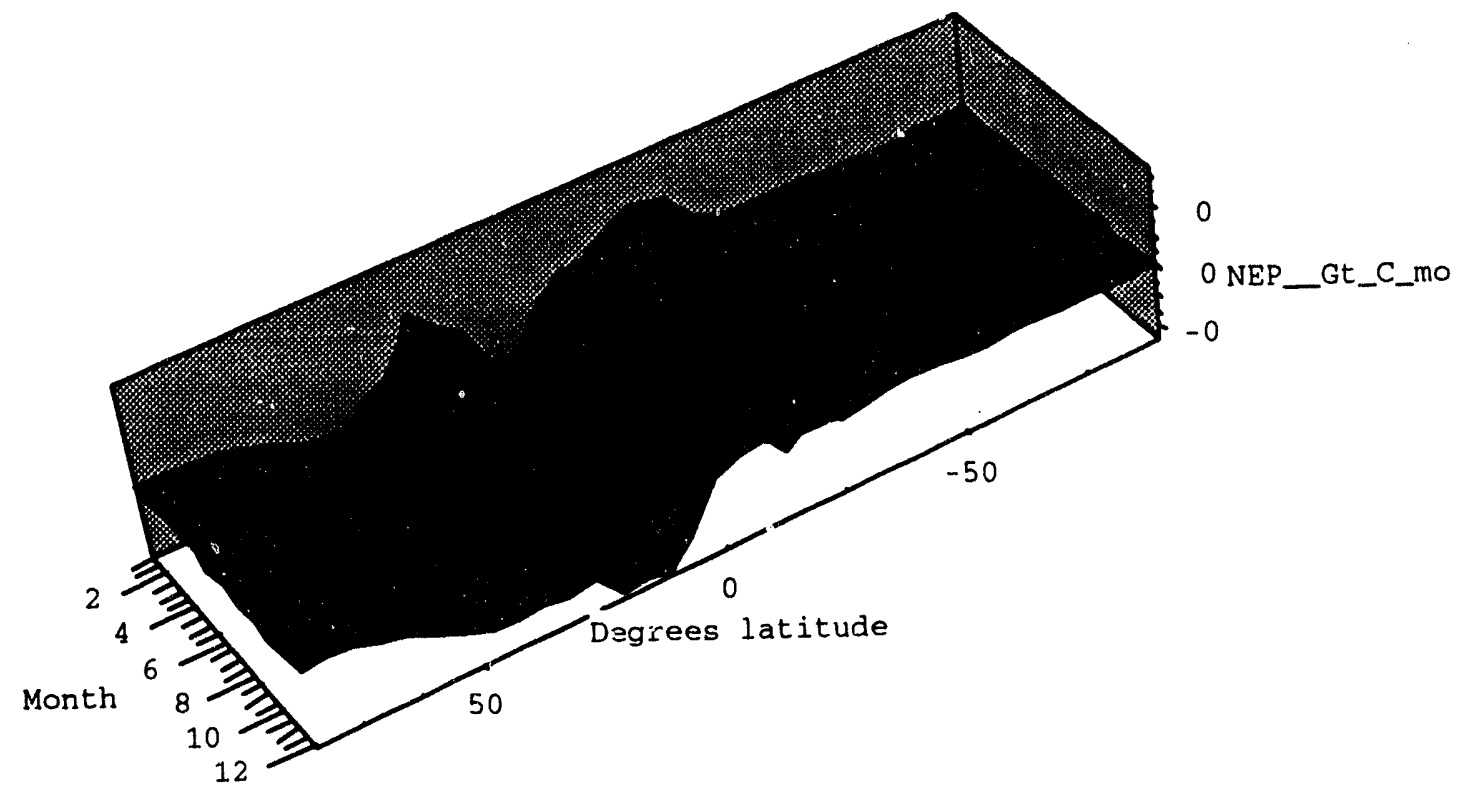

Fig. 5e. Net ecosystem production (gross primary production - plant respiration - soil respiration) for $5^{\circ}$ latitude increments summed over $360^{\circ}$ of longitude. The raw data that this graph was derived from was used as an input for GRANTOUR calculations of atmospheric $\mathrm{CO}_{2}$ 


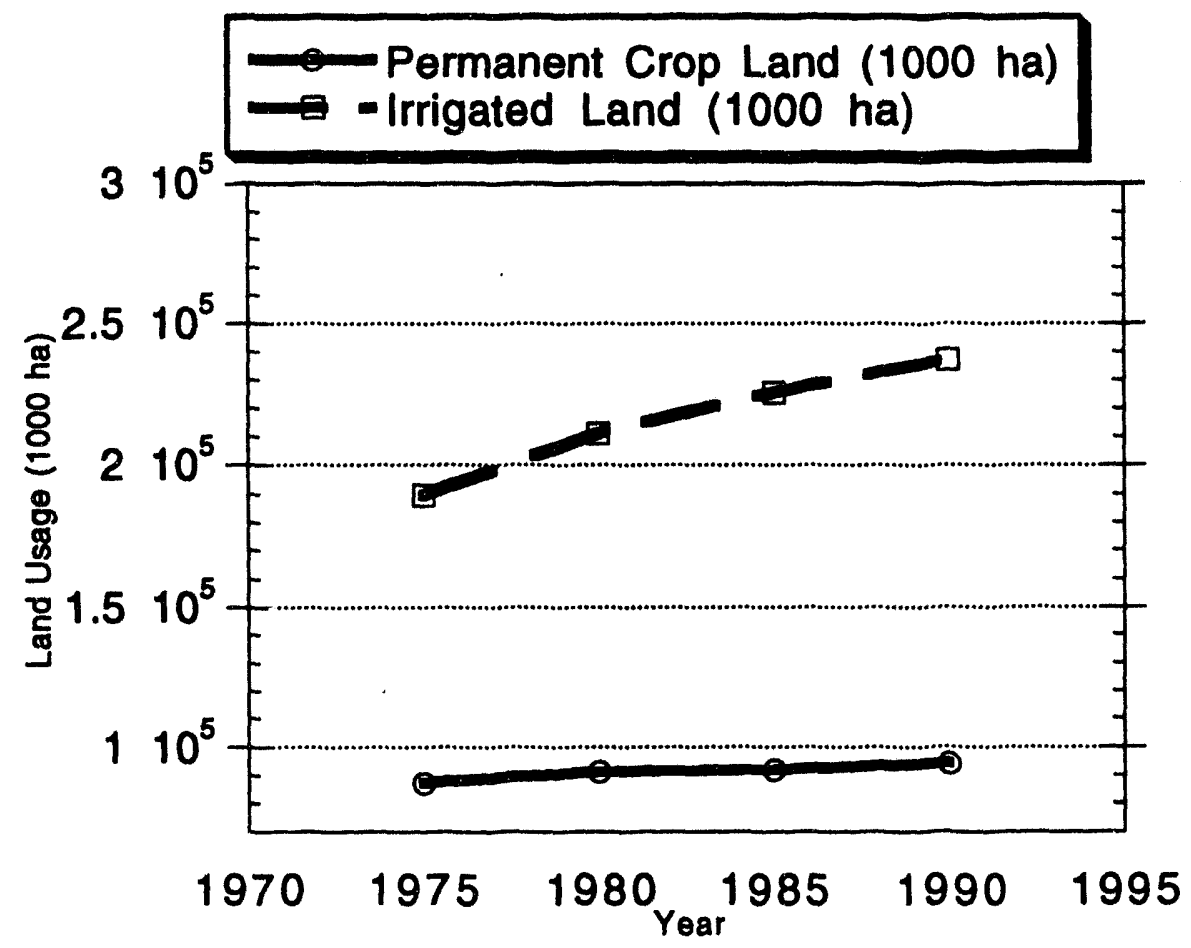

Figure 6. Land usage for irrigated crops and permanent crops.

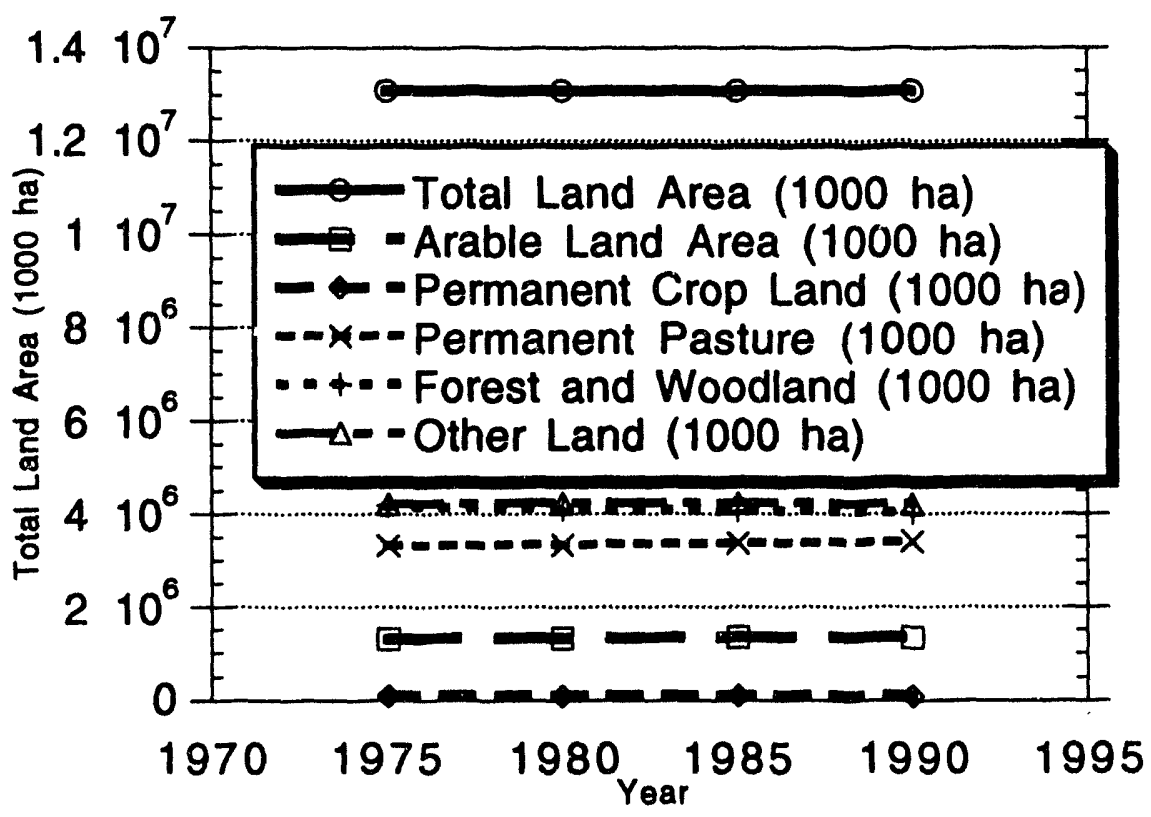

Fig. 7. Land use trends for various land use categories since 1975. Most categories are stable over this time period. 


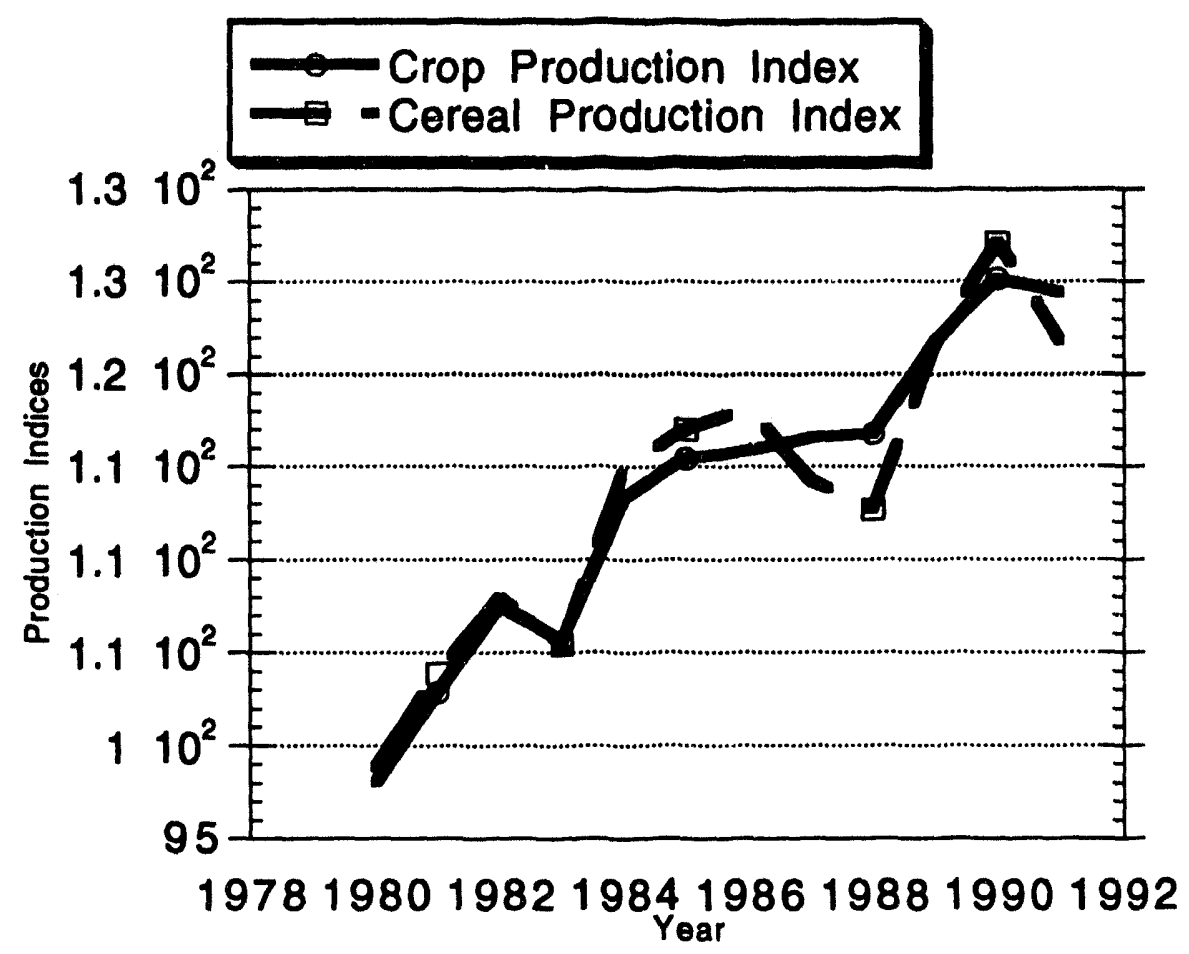

Fig. 8. Crop and cereal production indices since 1980. Indices for $1980=100$ and are unitless.

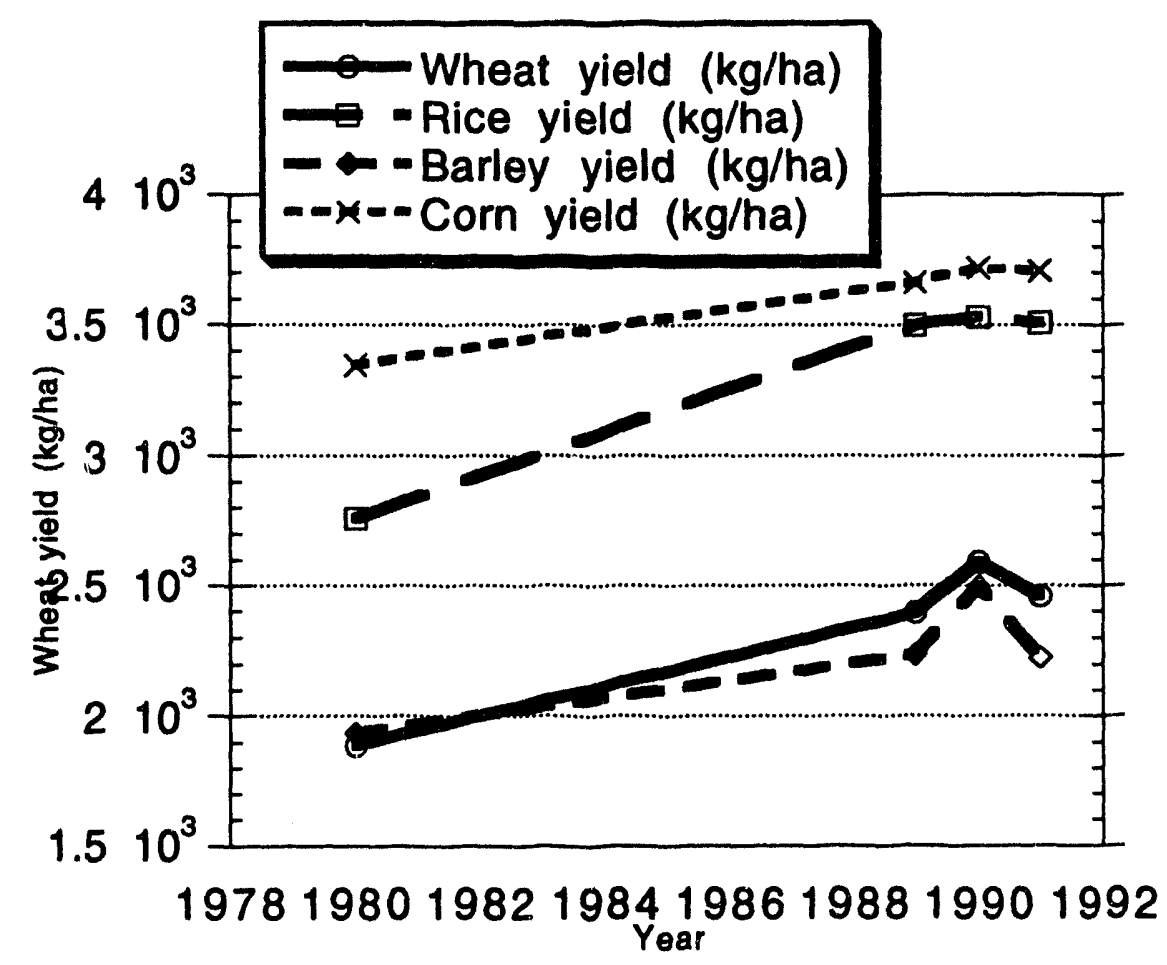

Fig. 9 Average global crop yield since 1980. 
Table 4. Worldwide crop production and contributions to global NPP for the top ten crops.

\begin{tabular}{|c|c|c|c|c|c|}
\hline Crop & $\begin{array}{l}\text { Global } \\
\text { Production } \\
\text { (106 metric } \\
\text { tons) }\end{array}$ & $\begin{array}{l}\text { Land Area } \\
\text { (106 ha) }\end{array}$ & $\begin{array}{l}\text { Economic } \\
\text { Yield } \\
\text { (Global } \\
\text { Average) } \\
\text { (metric ton } \\
\text { ha }^{-1} \mathrm{yr}^{-1} \text { ) }\end{array}$ & $\begin{array}{l}\text { NPP } \\
\left(\mathrm{g} \mathrm{C} \mathrm{m}^{-2}\right)\end{array}$ & $\begin{array}{l}\text { Annual } \\
\text { Net Global } \\
\text { Carbon } \\
\text { Fixed } \\
\left(10^{9} \text { metric }\right. \\
\left.\text { ton } \mathrm{C} \mathrm{yr}^{-1}\right)\end{array}$ \\
\hline Sugar cane & 1091 & 18.0 & 60.7 & 1400 & 0.25 \\
\hline Wheat & 551 & 224 & 2.46 & 430 & 0.96 \\
\hline Rice & 520 & 148 & 3.50 & 270 & 0.39 \\
\hline Maize & 479 & 129 & 3.70 & 510 & 0.66 \\
\hline Sugar beet & 297 & 8.4 & 35.1 & 500 & 0.042 \\
\hline Potato & 169 & 17.7 & 14.7 & 160 & 0.028 \\
\hline Barley & 154 & 76.2 & 2.22 & 250 & 0.19 \\
\hline Cassava & 126 & 15.7 & 9.80 & 130 & 0.020 \\
\hline $\begin{array}{l}\text { Sweet } \\
\text { potato }\end{array}$ & 103 & 9.2 & 13.6 & 260 & 0.024 \\
\hline Soybean & 69 & 55.4 & 1.86 & 200 & 0.11 \\
\hline Total & 3559 & & & & 2.67 \\
\hline All crops & 4520 & & & & \\
\hline
\end{tabular}

TERRA Improvements. The shortcomings of TERRA were recognized early on and a series of modifications were initiated to improve the ability of TERRA to predict ecosystem behavior under unusual conditions, e.g., high $\mathrm{CO}_{2}$ levels, by introducing more mechanistic components into TERRA submodels. These modifications needed are (1) introduction of plant morphological components (e.g., leaves, stem, branches, roots, storage), (2) effects of elevated $\mathrm{CO}_{2}$ on plant photosynthesis and growth (fertilization) and increase in water-use-efficiency, (3) improved description of senescence and phenological development, (4) improved description of mechanistic basis of canopy processes, (5) improved coupling of nitrogen cycle and carbon cycle including effect of leaf nitrogen on productivity, (5) improved mechanistic description of soil processes and soil pools of organic matter and nitrogen compounds, and (6) introduction of land use practices. Improvements on soil processes (5) began in FY93. Improvements in the other areas of weakness began in FY94.

TERRA Soil Submodel Development. During FY94, we have continued development of the soil portion of TERRA. We have begun work on the improvements of DNDC outlined above. This work will continue during FY94. Also, we have begun the incorporation of CENTURY into TERRA. After CENTURY is incorporated into TERRA and the modifications to DNDC are complete, DNDC will be combined with TERRA and CENTURY. This effort will begin in FY94 and will be completed in FY95. We will test DNDC against field data in FY95.

TERRA Canopy Processes. We have developed a detailed model of canopy processes including momentum transfer, transpiration, and $\mathrm{CO}_{2}$ diffusion and uptake by vegetation. This canopy model was developed for another project and tested in the Harvard Forest. A simplified version of this model is being developed for inclusion into TERRA to replace the TERRA's calculations of gross primary productivity and transpiration and to augment TERRA's capability for providing boundary conditions to GCM's. This work will continue through FY94. 
Land Use. We have explored the issues of land use in FY94 and will continue to do so for the balance of the fiscal year. Our goal is to determine how land use, in general, and humankind's agricultural practices, in particular, may significantly affect biogeochemical cycling of carbon and observations of atmospheric $\mathrm{CO}_{2}$ levels, including the long term trends, observed increases in the seasonal amplitude, and phase or seasonal structure of the seasonal cycle. While land for permanent crops (e.g., citrus orchards, vineyards, etc.) and irrigated land have increased somewhat over the last 15 years (Fig. 6), the overall use of land for agriculture has been relatively stable (Fig. 7). On the other hand crop and cereal production have increased rather substantially since 1980 (Fig. 8). This prodi ction increase has been due to rising levels of productivity (yield per land area). In Fig. 9 we show the average worldwide yield increases for four cereal crops. All data for Figs. 7, 8, and 9 were taken from FAO (1992). In Table 4, we show the economic yield production and biomass yield as NPP in gigatons $\mathrm{C} \mathrm{yr}-1$ for the ten crops with the highest global production. They produce a total NPP of about $2.7 \mathrm{Gt} \mathrm{C} \mathrm{yr-1}$ and they account for 78\% of the total production for all crops worldwide Assuming that the remaining crops have the corresponding biomass production on average as the top ten, then total estimated biomass NPP for all crops should be approximately $3.4 \mathrm{Gt} \mathrm{C} \mathrm{yr-1.} \mathrm{This} \mathrm{value} \mathrm{is} 6.5 \%$ of the global NPP estimated by TERRA for the potential vegetation case. We conclude that agriculture is a significant component of global NPP and we will be studying it further during FY94.

\section{Acknowledgment}

This work was performed under the auspices of the U.S. Department of Energy by the Lawrence Livermore National Laboratory under Contract No. W-7405-Eng-48. This work was funded in part by the Environmental Protection Agency under order number DW899 through the Athens Environmental Research Laboratory.

\section{References}

Arakawa, A., and V.R. Lamb, 1977. Computational design of the basic dynamical processes of the UCLA general circulation model. Methods in Computational Physics 17:173-265.

Barnett, V. 1976. The ordering of multivariate data. Journal of the Royal Statistical Society A $139: 318-355$.

Bebbington, A.C. 1978. A method of trimming for robust estimation of the correlation coefficient. Appl. Statistics 27:221-226.

Becker, R.A., J.M. Chambers, and A.R. Wilks. 1988. The New S Language. Wadsworth and Brooks. Pacific Grove, CA.

Botkin, D.B., J.F. Janak, and J.R. Wallis. 1972. Some ecological consequences of a computer model of forest growth. J. Ecol. 60:849-872.

Box, E.O. 1981. Macroclimate and plant forms: an introduction to predictive modeling in phytogeography. Dr. W. Junk Publishers, The Hague. 258 p.

Davidson, E.A. 1993. Soil water content and the ratio of nitrous oxide to nitric oxide emmitted from soil. p. 369-386. In Biogeochemistry of Global change: Radiatively Active Trace Gases (R.S. Oremland, ed.). Chapman and Hall. 
Dickinson, R.E., A. Henderson-Sellers, P.J. Kennedy, and M.F. Wilson. 1986. Biosphere-Atmosphere Transfer Scheme (BATS) for the NCAR Community Climate Model. NCAR Technical Note NCAR/TN-275+STR, National Center for Atmospheric Research, Boulder Co. 69 p.

Efron, B. 1965. The convex hull of a random set of points. Biometrika 52:331-343.

Geiger, R. 1965. World Atmosphere Series of Maps. Map No. WA6: Annual Effective Evapotranspiration. Darmstedt: Justus Perthes.

Grime, J.P. 1979. Plant strategies and vegetation processes. John Wiley and Sons.

Holdridge, L.R. 1947. Determination of world plant formations fro simple climatic data. Science 105:367-368.

Holdridge, L.R. 1967. Life Zone Ecology. Revised Edition. Tropical Science Center, San Jose, Costa Rica.

Kercher, J.R., and M.C. Axelrod, 1984: A process model of fire ecology and succession in a mixed-conifer forest. Ecology, 65, 1725-1742.

Kercher, J.R., S.M. Umschied, and D.W. Fledderman. 1988. Modelling dynamic spatial heterogeneity in a mixed-conifer landscape. SUPPL. BULL. ECO. SOC. AM. 69 (2): 190191. ABSTRACT.

Larcher, W. 1980. Physiological Plant Ecology. 2nd Edition. Springer-Verlag

Leemans, R., and W. P. Cramer. 1990. The IIASA database for mean monthly values of temperature, precipitation, and cloudiness on a global terrestrial grid. WP-90-41. International Institute for Applied Systems Analysis, Laxenburg, Austria.

Leith, H. 1975. Modeling the primary productivity of the world. p. 237-263. In Primary Productivity of the Bosphere (H. Leith and R.H. Whittaker,eds.) Springer-Verlag.

$\mathrm{Li}, \mathrm{C}$. 1992. A model of nitrous oxide evolution from soil driven by rainfall events: 1 . Model structure and sensitivity. J. of Geophysical Research 97(D9):9759-9776.

Lyons, W.B., P.A. Mayewski, M.J. Spencer, and M.S. Twickler. 1990. Nitrate concentrations in snow from remote areas: implication for the global NOx flux. Biogeochemistry 9:21-222.

Manaabe, F., R.J. Stouffer, M.J. Spellman, K. Bryan. 1991. Transient response of a couopled ocean-atmosphere model to gradual changes of atmospheric CO2 Part 1:Annual mean response. Journal of Climate 4:785-818.

Matthews,E. 1983. Global vegetation and land use: new high-resolution data bases for climate studies. J. of Climate and App. Meteorology 22:474-487.

Mathews,E. 1984. Vegetation, land-use and seasonal albedo data sets: documentation of archived data tape. NASA Technical Memorandum 86107, Goddard Institute for Space Studies, NY,NY.

McGuire,A.D., J.M. Melillo, L.A. Joyce, D.W. Kicklighter, A.L. Grace, B. Moore III, and C.J. Vorosmarty. 1992. Interactions between carbon and nitrogen dynamics in 
estimating net primary productivity for potential vegetation in North America. Global Biogeochemical Cycles 6:101-124.

Melillo, J.M., A.D. McGuire, D.W. Kicklighter, B. Moore III, C.J. Vorosmarty, and A.L. Schloss. 1993. Global climate change and terrestrial net primary production. Nature 363:234-240.

Muller,M.J. 1982. Selected Climatic Data for a Global Set of Standard Stations for Vegetation Science. Dr. W. Junk Publishers (Kluwer), Boston.

Neilson, R.P., G.A. King, and G. Koerper. 1992. Toward a rule-based biome model. Landscape Ecology 7:27-43.

NGDC. 1991. Global Ecosystems Database. EPA Global Climate Research Program. NOAA/NGDC Global Change Database Program. NGDC Key to Geophysical Records Documentation No. 25. National Geophysical Data Center, Boulder CO.

NOAA (Officials of the National Oceanic and Atmospheric Administration). 1974. Climates of the States Vol I-Eastern States and Vol II-Western States. Water Information Center, Inc.,Port Washington, NY.

Parton, W.J., D.S. Schimel, C.V. Cole, and D.S. Ojima. 1987. Analysis of factors controlling soil organic matter level in Great Plains grasslands. Soil Science Society of America Journal 51:1173-1179.

Penner, J.E., C.S. Atherton, J. Dignon, S.J. Ghan, J.J. Walton, and S. Hameed. 1991. Tropospheric nitrogen: a three dimensional study of sources, distribution, and deposition. J. of Geophysical Research 96:959-990.

Raich, J.W., E.B. Rastetter, J.M. Melillo, D.W. Kicklighter, P.A. Steudler, B.J. Peterson, A.L. Grace, B. Moore III, and C.J. Vorosmarty. 1991. Potential net primary productivity in South America: application of a global model. Ecological Applications 1:399-429.

Reed, K.L. and R.H. Waring. 1974. Coupling of environment to plant response: a simulation model of transpiration. Ecology 55:62-72.

Running, S.W. 1984. Documentation and preliminary validation of H2OTRANS and DAYTRANS, two models for predicting transpiration and water stress in western coniferous forests. Research Paper RM-252, Rocky Mountain Forest and Range Experiment Station, USDA Forest Service, Fort Collins, CO. 45 p.

Staub, B. and C. Rosenzweig. 1987. Global digital data sets of soil types, soil texture, surface slope, and other properties: documentation of archived tape data. NASA Technical Memorandum No. 100685. NTIS, Springfield, VA.

Thornthwaite, C.W. and J.R. Mather. 1957. Instructions and tables for computing potential evapotranspiration and the water balance. Publ. Climatol. Drexel Institute of Technol. 10:180-311.

Tukey, J.W. 1977. Exploratory Data Analysis. Addison-Wesley, Reading, MA.

Turton,S.M. 1986. Solar radiation under cloudless skies. Weatherwise 39:223-224. 
Vorosmarty, C.J., B. Moore III, A.L. Grace, M.P. Gildea, J.M. Melillo, B.J. Peterson, E.B. Rastetter, and P.A. Steudler. 1989. Continental scale models of water balance and fluvial transport: an application to South America. Global Biogeochemical Cycles 3:241265.

Waiton, J.J, M.C. MacCracken, S.J. Ghan. 1988. A global scale Lagrangian trace species model of transport, transformation, and removal processes. J. of Geophysical Research 93:8339-8354.

Whittaker, R.H. 1975. Communities and Ecosystems. MacMillan Publishing Co. New York.

Woodward, F.I. 1987. Climate and Plant Distribution. Cambridge University Press,New York. 

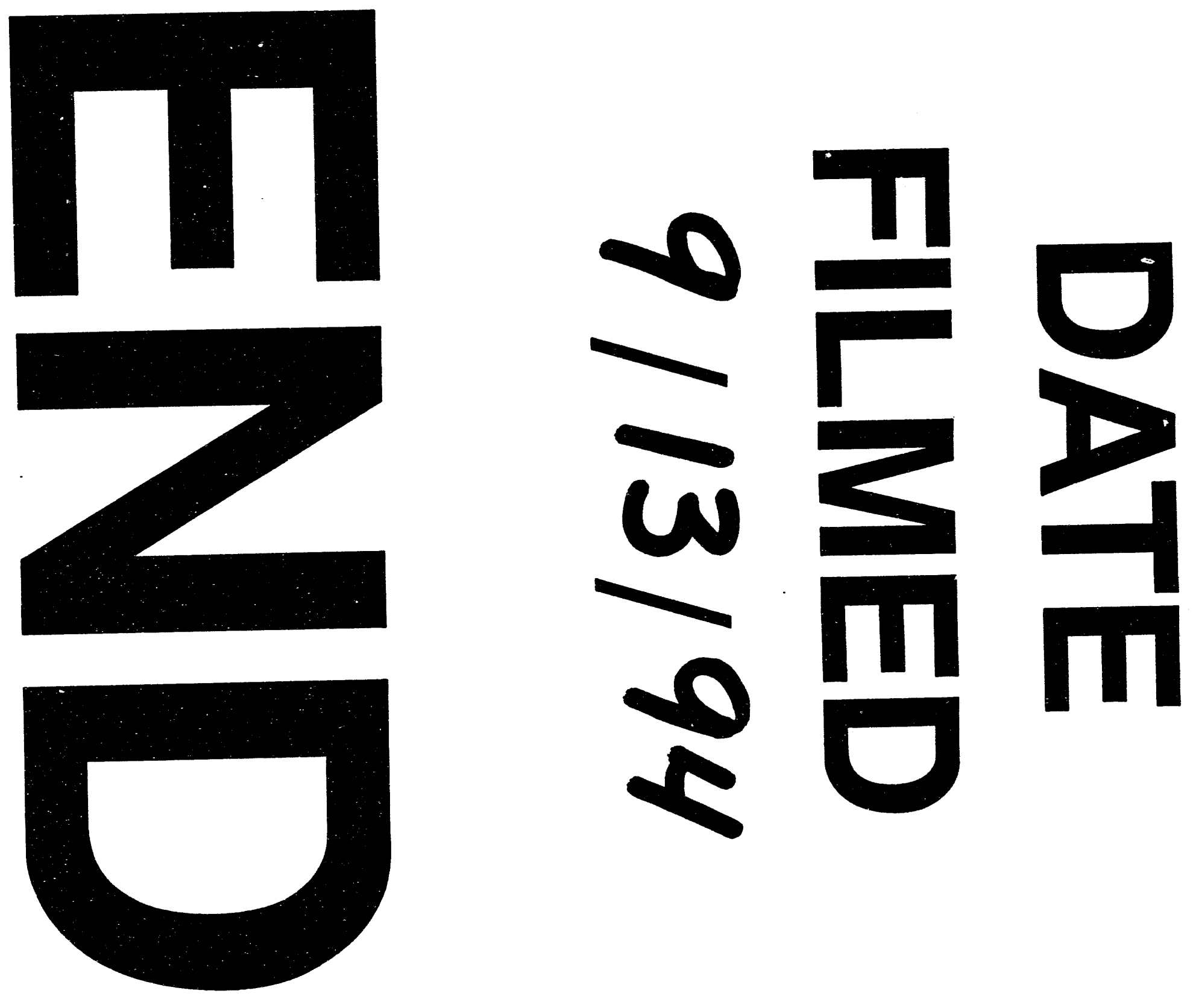
